\title{
Incydent czy akt agresji w rejonie Cieśniny Kerczeńskiej?
}

$\mathrm{I}$ nspiracją do napisania niniejszego artykułu była publikacja w magazynie „Okręty Wojenne” autorstwa Aleksandra Mitrofanova (Litwa) Incydent w rejonie Cieśniny Kerczeńskiej ${ }^{1}$, który wpisuje się w narrację rosyjskiej propagandy, uprawianej na terytorium Polski. Czytając powyższy artykuł, trudno się nie zgodzić z twierdzeniem prof. Andrzeja Nowaka, że w Polsce dochodzi do bardzo niepokojącego zjawiska w postaci rosnącego putinofilstwa, co wiąże się z infiltracją przez rosyjskie służby polskich mediów i internetu, a "główną pożywką dla upowszechniania tych nastrojów stała się Ukraina"2. Rosyjski badacz Walery Sołowiej w swojej bardzo dobrej książce Broń absolutna. Podstawy wojny psychologicznej i manipulacja mediami pisał o wojnie informacyjnej, której celem jest zniekształcenie psychiki i deformacja intelektu przeciwnika. Głównym zadaniem takiej wojny staje się zniszczenie systemu komunikacji wroga. Definicja wojny informacyjnej zawiera dwa podstawowe aspekty. Po pierwsze, są to działania w zakresie wojny cybernetycznej (aspekt informacyjno-technologiczny), a po drugie - wywieranie wpływu na społeczeństwo, świadomość i podświadomość jednostek strony przeciwnej przy jednoczesnej ochronie własnej przestrzeni informacyjnej (aspekt informacyjno-psychologiczny) ${ }^{3}$. W tym przypadku na użytek zewnętrzny państwa uprawiają propagandę, innymi słowy manipulują mediami.

Rosja Putina - autor celowo rozróżnia Rosję od reżimu Władimira Putina ${ }^{4}$ - powróciła do polityki imperialnej opartej na sile militarnej oraz surowcach energetycznych ${ }^{5}$. Kreml, dążąc do przywrócenia sobie statusu supermocarstwa, nie stawia na modernizację i rozwój systemu politycznego i ekonomicznego, lecz wykorzystuje ww.

\footnotetext{
A. Mitrofanov, Incydent w Cieśninie Kerczeńskiej, „Okręty Wojenne” 2019, nr 1, s. 96-103.

A. Nowak, Koniec podległości, „Nowa Europa Wschodnia” 2016, nr 1, s. 11.

В. Соловей, Абсолютное оружие. Основы психологической войны и медиаманипулирования, «Издательство «Э» 2015.

4 Zob. В. Сурков, Долгое государство Путина, „Независимая газета” 11.02.2019.

5 B. Bieleszczuk i in., Raport PISM: Energia i obronność w regionie nordycko-bałtyckim, Warszawa 2018.
} 
narzędzia w konfrontacji z Zachodem. Słabość rosyjskiej gospodarki nie pozwala FR na konkurowanie z Zachodem na polu rywalizacji ekonomicznej. Odrzucając model współpracy z Zachodem w ramach chociażby Partnerstwa dla Pokoju (NATO) lub Partnerstwa Wschodniego (UE), Rosja celowo wybrała model konfrontacji. Zdaniem strategów Kremla polityka destabilizacji sytuacji w niektórych państwach obszaru poradzieckiego (Mołdawia, Gruzja, Ukraina), w tym przy pomocy siły militarnej oraz tzw. polityki rurociągów, pozwoli Moskwie na ostudzenie proeuropejskiego i proatlantyckiego zapału ostatnich. Neoimperialna polityka Kremla zakłada m.in. przywrócenie niekwestionowanych przez społeczność międzynarodową wpływów i uznania wyłączności jej interesów na obszarze byłego ZSRR. „Instalując” bądź wspierając konflikty niskiej intensywności w państwach regionu, Rosja uzyskuje możliwości prowadzenia działań podprogowych w ramach wojny hybrydowej. Nawet w sytuacji bezpośredniej inwazji (Mołdawia, Gruzja, Ukraina) dąży do przedstawienia swojej agresji jako interwencji humanitarnej. Oprócz siły militarnej oraz czynnika energetycznego Rosja pozyskała niemniej ważne narzędzie wpływu w postaci propagandy (manipulacji mediami). Zdając sobie sprawę z wpływu opinii publicznej na rządy państw demokratycznych, Rosja bardzo dobrze przygotowała się do prowadzenia wojny informacyjnej w konfrontacji z Zachodem. Usankcjonowanie tego typu działań miało miejsce w tzw. doktrynie Gerasimowa, mówiącej o wojnie nowej generacji (wojnie hybrydowej), której ważnym elementem jest rywalizacja w przestrzeni informacyjnej (информационное противоборство) $)^{6}$. Polityczne, energetyczne i militarne konflikty Rosji z Gruzją (2008) i Ukrainą (2014) stały się swego rodzaju polem doświadczalnym ${ }^{7}$. Powyższe warunkuje zaliczanie Rosji do kategorii mocarstw agresywnych.

W marcu 2015 roku minister obrony FR Siergiej Szojgu oświadczył, że środki masowego przekazu stały się rodzajem broni. W swojej wypowiedzi minister zaznaczył, że dzisiaj słowo, kamera, fotografia, internet oraz generalnie informacja stały się jeszcze jednym rodzajem broni sił zbrojnych. Broń informacyjną można wykorzystywać w dobrym bądź złym celu. Powyższa broń towarzyszyła naszemu państwu zarówno podczas klęsk, jak i zwycięstw

Wspomniany wyżej artykuł autorstwa Aleksandra Mitrofanova opublikowany w polskim czasopiśmie wpisuje się w tego typu działania. Często podejmowane są one na polu informacyjnym potencjalnego przeciwnika, wtedy Rosja pilnie strzeże dostępu do własnej przestrzeni informacyjnej. W artykule autor dokonał bardzo prostej manipulacji, przedstawiając tzw. incydent w Cieśninie Kerczeńskiej (na dodatek na podstawie relacji rosyjskiej FSB) jako jednostkowe zdarzenie bez przedstawienia jego

6 В. Герасимов, Ценность науки в предвидении, «Военно-промышленный курьер» 27.02.2013, № 8 (476).

7 В. Соловей, op. cit.; Wojna hybrydowa Rosji przeciwko Ukrainie w latach 2014-2016, red. W. Baluk, M. Doroszko, Lublin 2017, s. 131 i n.; O. Wasiuta, S. Wasiuta, Wojna hybrydowa Rosji przeciwko Ukrainie, Kraków 2017.

8 Б. Шапталов, Изнанка российско-украинского конфликта, или как поссорились соседи, Центрполиграф 2016. 
kontekstu, związanego z rosyjską aneksją Krymu i kontynuowaniem agresywnej polityki na Donbasie. Autora nie interesuje pogwałcenie przez Rosję prawa międzynarodowego, porozumien dwustronnych, suwerennych praw Ukrainy na morzach Czarnym i Azowskim oraz w Cieśninie Kerczeńskiej. Pomijając powyższe uwarunkowania, autor, podobnie jak rosyjska propaganda, metodą manipulacji oraz tworzenia „faktów alternatywnych" próbował narzucić czytelnikowi narrację naruszenia przez Siły Morskie Ukrainy rosyjskich wód terytorialnych, podjęcia działań zagrażających Mostowi Kerczeńskiemu (wybudowany nielegalnie) bądź naruszenia przez stronę ukraińską prawa międzynarodowego (Konwencji o prawie morza). Metody „robienia z kata ofiary” bądź „odwracania kota ogonem” od dawna są stosowane przez rosyjską propagandę 9 . Popieranie rosyjskiej narracji propagandowej utrwala Moskwę w przekonaniu, że prawo rodzi się z bezprawia.

Podstawowym problemem badawczym wymagającym zgłębienia w niniejszym opracowaniu nie będzie metodyka praktycznego oddziaływania rosyjskiej propagandy, lecz analiza uwarunkowań, teoretycznych i praktycznych aspektów nazywanych potocznie incydentem w Cieśninie Kerczeńskiej. Pytanie badawcze autor zawarł w tytule artykułu, umieszczając je wokół dociekań na temat tego, czy pod koniec listopada 2018 roku w Cieśninie Kerczeńskiej doszło do incydentu, czy do aktu agresji. Wnioski zostaną wyciągnięte na podstawie studium przypadku analizowanego w kontekście wojny rosyjsko-ukraińskiej.

\section{Kwalifikacja zdarzenia (aspekt teoretyczny)}

Stosowane w naukach prawnych pojęcie „kwalifikacja prawna” oznacza przyporządkowanie czynu (zdarzenia) określonemu przepisowi. W teorii prawa pojęcie to ma dwa znaczenia. Pierwsze dotyczy procesu myślowego, za którego pomocą odnosimy konkretne zdarzenia do przepisu prawnego, natomiast drugie możemy połączyć $\mathrm{z}$ wynikiem tego procesu w sytuacji właściwego rozpoznania znamion przestępstwa ${ }^{10}$. W naukach społecznych precyzyjne posługiwanie się aparatem pojęciowym oraz dokładnym opisem sytuacji i zdarzeń również ma bardzo ważne znaczenie. W kontekście manipulacji mediami wspomniany wyżej rosyjski badacz Walery Sołowiej pisał o znaczeniu dobrze dobranej nazwy zdarzenia. Podkreślając wagę problemu, użył nawet znanego w Rosji i trafnego określenia „как вы яхту назовёте, так она и поплывёт” (jak się nazwie jacht, tak on będzie pływał) ${ }^{11}$. Z tego względu warto kilka słów poświęcić ogólnym aspektom kwalifikacji zdarzenia.

Leksykony lub encyklopedie z zakresu nauk prawnych oraz społecznych nie nadają wyrazowi „incydent” szczególnego znaczenia. Natomiast na podstawie definicji słownikowych wyraz ten oznacza zdarzenie, zajście lub wypadek, a incydentalny znaczy to

9 B. Borowik, E. Kirwiel, The Media System in the Russian Federation. Selected issues, „Wschód Europy. Studia humanistyczno-społeczne" 2018, nr 1, s. 31-35.

10 Mała encyklopedia prawa, red. U.K. Kalina-Prasznic, Warszawa 2005, s. 235.

11 В. Соловей, op. cit. 
samo co uboczny lub przypadkowy ${ }^{12}$. Z kolei w słowniku języka rosyjskiego „incydent” (инцидент) oznacza niemiły wypadek, nieporozumienie lub zderzenie (столкновенue $)^{13}$. W prawie „zdarzenia cywilnoprawne” są dzielone na dwie grupy: 1) niezależne od woli podmiotów prawa (zdarzenia w ścisłym tego sława znaczeniu) oraz 2) zależne od woli określonych podmiotów (działania) ${ }^{14}$.

Nawet powierzchowna analiza tzw. incydentu w Cieśninie Kerczeńskiej pokazuje, że mamy do czynienia zarówno ze strony Ukrainy (przebazowanie kutrów artyleryjskich z portu w Odessie do portu w Mariupolu), jak i ze strony Rosji (zablokowanie, ostrzelanie i przejęcie ukraińskich okrętów i marynarzy) z celowym działaniem, aktem zależnym od woli podmiotów prawa międzynarodowego. $\mathrm{W}$ tej sytuacji istotne znaczenie mają motywy i kontekst podejmowanych działań. Powyższe warunkuje przedstawienie tzw. incydentu w Cieśninie Kerczeńskiej nie jako przypadku niezależnego od woli podmiotów, lecz jako zderzenia (столкновения) stron konfliktu rosyjsko-ukraińskiego, wywołanego i będącego następstwem agresji Rosji wobec Ukrainy, konsekwencją aneksji Krymu i wojny na Donbasie. Zatem nie mamy do czynienia ze zwykłym incydentem, lecz z kolejnym aktem agresji tym razem na morzu. Przyjrzymy się temu, jak są definiowane: 1) agresja w prawie międzynarodowym oraz 2) międzynarodowy konflikt zbrojny w naukach społecznych.

Próby zdefiniowania agresji $\mathrm{w}$ prawie międzynarodowym zostały podjęte jeszcze w ramach Ligi Narodów z inicjatywy ZSRR. Państwo było uznawane za agresora w myśl Konwencji Londyńskiej o określeniu napaści podpisanej 3 lipca $1933 \mathrm{roku}^{15}$. Pomimo troski o pokój, kolektywne bezpieczeństwo oraz przeciwdziałanie agresji na forum Ligi Narodów polityka Związku Radzieckiego świadczy o relatywizmie moralnym. Prawo Kalego aktualnie obowiązuje nawet $\mathrm{w}$ rosyjskiej historiografii, gdzie w podręczniku z historii stosunków międzynarodowych możemy przeczytać o agresji III Rzeszy wobec Czechosłowacji i ZSRR, natomiast nie ma opisu agresji radzieckiej wobec Polski, Finlandii, państw bałtyckich, nie mówiąc już o współodpowiedzialności ZSRR za rozpoczęcie II wojny światowej ${ }^{16}$.

12 W. Kopaliński, Słownik wyrazów obcych i zwrotów obcojęzycznych z almanachem, Warszawa 1994, s. 226.

13 С. Ожегов, Ю. Шведова, Толковый словарь русского языка, Москва 2002, s. 250.

14 Mała encyklopedia prawa..., s. 773.

15 Agresorem jest państwo, które pierwsze popełni jeden z następujących czynów: 1) wypowie wojnę innemu państwu; 2) dokona najazdu za pomocą sił zbrojnych na terytorium innego państwa, nawet bez wypowiedzenia wojny; 3) zaatakuje za pomocą sił lądowych, morskich lub powietrznych terytorium, okręty lub samoloty innego państwa, nawet bez wypowiedzenia wojny; 4) zastosuje blokadę morską wybrzeża lub portów innego państwa; 5) udzieli poparcia zbrojnym bandom, które zorganizowały na jego terytorium i dokonują napadu na terytorium innego państwa, lub odmówi, pomimo żądania państwa napadniętego, wydania na własnym terytorium wszelkich będących w jego mocy zarządzeń w celu pozbawienia tych band pomocy lub opieki. W. Góralczyk, S. Sawicki, Prawo międzynarodowe publiczne w zarysie, Warszawa 2015, s. 347-348.

16 А. Протопопов, В. Козьменко, Н. Елманова, История международных отночений и внешней политики России 1648-2005, Москва 2006, s. 231-257. 
Sprawami nowego porządku międzynarodowego, w tym pokoju i bezpieczeństwa, zajęła się Organizacja Narodów Zjednoczonych (ONZ). Ambasador USA przy ONZ W. Austin swego czasu powiedział, że wraz z powstaniem ONZ nastąpiła przewaga sił pokoju nad starą zasadą równowagi si1 ${ }^{17}$. Uniwersalna organizacja międzynarodowa miała za zadanie zajmować się m.in. utrzymaniem międzynarodowego pokoju i bezpieczeństwa oraz reagowaniem w sytuacji aktów agresji i naruszenia pokoju. Jednocześnie Karta Narodów Zjednoczonym precyzuje, że żadne postanowienie dokumentu nie narusza prawa państw członkowskich do przeciwstawienia się zbrojnej napaści ${ }^{18}$.

W 1974 r. Zgromadzenie Ogólne ONZ przyjęło uchwałę definiującą pojęcie „,agresji”. Należy podkreślić, że rezolucje ZO ONZ nie mają mocy prawnie wiążącej ${ }^{19}$. Agresja - użycie sił zbrojnych przez jedno państwo przeciwko suwerenności, integralności terytorialnej lub politycznej niezawisłości innego państwa lub też użycie ich w inny sposób niezgodny z postanowieniami Karty Narodów Zjednoczonych. Uchwała wyszczególnia takie przykłady agresji, jak (art. 3):

a) inwazja lub atak dokonany przez siły jednego państwa na terytorium drugiego państwa albo okupacja wojskowa, nawet czasowa, będąca następstwem takiej inwazji lub ataku, albo aneksja, przy użyciu siły, terytorium drugiego państwa lub części tego terytorium;

b) bombardowanie przez siły zbrojne jednego państwa terytorium drugiego państwa albo użycie przez państwo jakiejkolwiek broni przeciwko terytorium drugiego państwa;

c) blokada portów lub wybrzeża państwa przez siły zbrojne innego państwa;

d) atak dokonany przez siły zbrojne jednego państwa na siły lądowe, morskie lub powietrzne albo flotę morską lub powietrzną drugiego państwa;

e) użycie sił zbrojnych jakiegoś państwa, które znajdują się na terytorium drugiego państwa na mocy porozumienia z państwem przyjmującym, w sposób naruszający warunki ustalone $\mathrm{w}$ tym porozumieniu lub przedłużenie obecności tych sił zbrojnych na danym terytorium poza okres przewidziany w porozumieniu;

f) wyrażenie przez państwo zgody, by jego terytorium, które oddało do dyspozycji innemu państwu, było wykorzystane do dokonania agresji przeciwko państwu trzeciemu;

g) wysyłanie przez jakieś państwo w imieniu tego państwa zbrojnych band, grup, oddziałów nieregularnych lub najemników, które dokonują zbrojnych działań przeciwko drugiemu państwu o takiej wadze, że równają się one aktom wymienionym powyżej lub poważnemu zaangażowaniu się na tym obszarze ${ }^{20}$.

17 H. Kissinger, Dyplomacja, Warszawa 2002, s. 500.

18 Karta Narodów Zjednoczonych, http://www.bb.po.gov.pl/Prawa/PNZ/KNZ.pdf, inf. 22.07.2019.

19 W. Góralczyk, S. Sawicki, op. cit., s. 347-348.

20 R. Bierzanek, J. Symonides, Prawo międzynarodowe publiczne, Warszawa 2004, s. 390. 
W radzieckiej oraz rosyjskiej literaturze przedmiotu z racji chociażby mitu „państwa miłującego pokój” problematyce tej poświęcano wiele uwagi w ramach studiów nad stosunkami międzynarodowymi oraz prawem międzynarodowym ${ }^{21}$.

Konflikt międzynarodowy najczęściej jest definiowany jako sprzeczność pomiędzy dwoma lub większą liczbą państw wynikającą z różnicy interesów. Stopniowe bądź gwałtowne ujawnienie sprzeczności następuje w trakcie narzucenia swoich racji przez strony w wyniku działań politycznych, ekonomicznych bądź militarnych. Narzucenie swoich racji odbywa się za pomocą środków werbalnych (protest, sprzeciw, groźba) oraz podjęcia bezpośrednich działań w postaci zerwania stosunków dyplomatycznych, groźby użycia siły bądź jej użycia. Pojęcie konfliktu odróżniamy od rywalizacji państw bądź kryzysu w relacjach między państwami. Dlatego, jak zauważyła Katarzyna Piskrzyńska, ważny jest moment powstania tzw. kryzysowego napięcia, w którym dochodzi do ujawnienia się sprzeczności oraz powstania jądra konfliktu międzynarodowego ${ }^{22}$. Konflikt międzynarodowy odróżniamy od konfliktu wewnętrznego, który przebiega w obrębie danego państwa. Należy jednak zaznaczyć, że bardzo często dochodzi do umiędzynarodowienia konfliktów wewnątrzpaństwowych przez wysyłanie do państw trzecich doradców, broni, ekspedycji wojskowej, a także przez wywieranie presji dyplomatycznej, informacyjnej, ekonomicznej i innej ${ }^{23}$. Fazy konfliktu: 1) sprzeczności, 2) sporu, 3) kryzysu, 4) konfrontacji, 5) pokojowego uregulowania konfliktu ${ }^{24}$.

Rosyjski badacz M. Szumiłow konfliktem międzynarodowym nazywa spór, rywalizację, walkę albo nawet napięcia między dwoma lub większą liczbą państw, które są jego bezpośrednimi uczestnikami, stronami konfliktu. W stosunkach międzynarodowych do stron konfliktu zaliczamy przede wszystkim państwa lub grupy państw (sojuszy), natomiast w konfliktach wewnętrznych głównymi aktorami są partie polityczne, ruchy narodowe, wyznaniowe i inne, a także władze. Profesor podkreślił, że ostatnimi czasy w konfliktach wewnętrznych i międzynarodowych coraz większe znaczenie uzyskują niepaństwowi uczestnicy (ruchy regionalne i międzynarodowe) ${ }^{25}$. Powyższe wskazuje na hybrydowość współczesnych konfliktów międzynarodowych.

Rosja odziedziczyła nie tylko miejsce ZSRR w Radzie Bezpieczeństwa ONZ, ale także relatywizm moralny w ocenie swoich i cudzych naruszeń prawa międzynarodowego. Minister Spraw Zagranicznych FR Siergiej Ławrow oraz Rada Federacji Rosji wezwali ONZ do potępienia agresji państw NATO wobec Federalnej Republiki Jugosławii w 1999 roku oraz do pociągnięcia do odpowiedzialności prawno-międzynarodo-

21 Zob. Ю. Рыбаков, Вооружённая агрессия - тягчайшее международное преступление, Москва 1980; С. Тишков, Агрессия как международное преступление, Москва 2017 (диссертация, научный руководитель: проф. А. Автономов).

22 K. Piskrzyńska, Kryzysy i konflikty międzynarodowe w wymiarze regionalnym. Rozważania teoretyczne, „De Doctrina Europea, Roczniki Instytutu Europeistyki” 2008, vol. V, s. 96.

23 Ibidem.

24 Ibidem.

25 М.М. Шумилов, „Современные конфликты и проблемы их урегулирования” (Учебнометодический комплекс по курсу), Издательство «СЗАГС» 2004, с. 35. 
wej państwa, które dokonały agresji2 ${ }^{26}$. Jednak wśród rosyjskich polityków i ekspertów próżno szukać podobnej kwalifikacji działań Federacji Rosyjskiej w stosunku do Gruzji (2008) lub Ukrainy (2014).

\section{Kwalifikacja zderzenia (wymiar rzeczywisty)}

Zatem kto jest agresorem, a kto ofiarą agresji oraz jaki był kontekst tzw. incydentu w Cieśninie Kerczeńskiej, postaramy się zarysować w dalszej części artykułu.

Aneksja Krymu została dokonana przez Federację Rosyjską w wyniku zbrojnej agresji wobec Ukrainy $\mathrm{z}$ naruszeniem wszelkich norm prawa międzynarodowego. Analiza działań Rosji w lutym i marcu 2014 roku w kontekście przytoczonej powyżej definicji agresji (Rezolucja ZO ONZ z 1974 r.) nie pozostawia co do tego żadnych wątpliwości. Działania Federacji Rosyjskiej były inwazją sił zbrojnych jednego państwa na terytorium drugiego państwa oraz czasową okupacją (art. 3a definicji) umożliwiającą przeprowadzenie tzw. referendum oraz aneksję półwyspu. 27 lutego 2014 roku oddziały specjalne Sił Zbrojnych FR bez znaków rozpoznawczych zajęły budynki Rady Najwyższej i Rządu Autonomicznej Republiki Krymu, wspierając dokonanie przewrotu przez miejscowych separatystów. W dalszej części operacji na ukraiński półwysep Rosja przerzuciła ze swojego terytorium ok. 5-6 tys. żołnierzy bez znaków rozpoznawczych, zwanych potocznie „zielonymi ludzikami” ${ }^{27}$. Zostali oni wspólnie z jednostkami rosyjskiej Floty Czarnomorskiej wykorzystani do blokowania w miejscach stacjonowania jednostek Sił Zbrojnych Ukrainy ${ }^{28}$. Początkowo Rosja zaprzeczała faktom wysłania na Krym jednostek Sił Zbrojnych FR. Jednak po dokonaniu formalnej aneksji Władimir Putin oświadczył, że decyzja o tzw. przyłączeniu Krymu do Rosji zapadła w wąskim gronie w nocy z 22 na 23 lutego, a regularne jednostki armii rosyjskiej zostały użyte na terytorium Ukrainy przez prezydenta FR na podstawie decyzji Rady Federacji $(1.03 .2014)^{29}$. Wojskowi biorący udział w operacji militarnej na Krymie zostali odznaczeni medalem Ministerstwa Obrony FR „Za powrót Krymu / 20.02.2014-18.03.2014”. Potwierdza to fakt, że operacja militarna rozpoczęła się kilka dni wcześniej aniżeli wy-

26 Совет Федерации принял Заявление в связи с 20-летней годовщиной начала военной операции НАТО против Югославии, http://council.gov.ru/events/news/102603/, inf. 17.07.2019.

27 Dnia 1.10.2016 roku wojskowa prokuratura Ukrainy podała nazwy regularnych jednostek SZ FR, które uczestniczyły w zbrojnej aneksji: 1) 31. brygada desantowo-szturmowa Wojsk Powietrzno-Desantowych, 2) 45. pułk specjalnego przeznaczenia WPD, 3) 98. dywizja powietrzno-desantowa WPD, 4) 76. dywizja desantowo-szturmowa WPD, 5) 18. brygada zmechanizowana, 6) 15. brygada zmechanizowana sił pokojowych FR oraz 7) jednostki 58. armii Południowego Okręgu Wojskowego FR. Военная прокуратура Украины обнародовала список российских подразделений, оккупировавших Крым, https://gordonua.com/news/crimea/voennaya-prokuratura-ukrainy-obnarodov ala-spisok-rossiyskih-podrazdeleniy-okkupirovavshih-krym-152672.html, inf. 18.07.2019.

28 A. Wilk, Rosyjska interwencja wojskowa na Krymie, http://www.osw.waw.pl/pl/publikacje/analizy/2014-03-05/rosyjska-interwencja-wojskowa-na-krymie, inf. 25.08.2014.

29 Путин рассказал „России 1”, как вернул Крым и спас Януковича, http://www.vesti.ru/doc. html?id=2412450, inf. 25.08.2014. 
nika to $\mathrm{z}$ wypowiedzi Władimira Putina, a decyzja Rady Federacji jedynie przypieczętowała prowadzoną już od kilku dni akcję militarną.

W aneksji części terytorium Ukrainy uczestniczyły także oddziały Samoobrony Krymu. W roku 2018 Prokurator Generalny Ukrainy Jurij Łucenko poinformował, że w toku postępowania udało się ustalić tożsamość 900 osób z ok. 2000 bojowników Samoobrony Krymu ${ }^{30}$. Ponadto w swoich działaniach Rosja wykorzystała nieregularne formacje wojskowe, takie jak Grupa Wagnera, Grupa Girkina-Striełkowa, Kozaków oraz Czeczeńców z batalionu „Wostok”. Powyższe wskazuje, że działania Rosji odpowiadają mianu agresji również w pkt g (art. 3) definicji, gdzie czytamy m.in. o wysyłanych oddziałach nieregularnych i najemnikach, dokonujących zbrojnych działań przeciwko drugiemu państwu.

Ponadto w trakcie operacji militarnej związanej z aneksją Krymu Federacja Rosyjska wykorzystała jednostki i okręty Floty Czarnomorskiej stacjonującej na terytorium Ukrainy w Sewastopolu i na Krymie w sposób naruszający ustalone warunki (art. 3 pkt e). W maju 1997 roku Rosja podpisała z Ukrainą Porozumienie o statusie i warunkach stacjonowania Floty Czarnomorskiej FR na terytorium Ukrainy. Dokument przewidywał m.in., że stacjonujące na Krymie jednostki Sił Zbrojnych FR będą szanować suwerenność Ukrainy, przestrzegać jej ustawodawstwa oraz nie będą wtrącać się w wewnętrzne sprawy państwa (art.6, ust. 1). Ponadto Rosja miała uzgadniać wszelkie ruchy swoich jednostek poza miejscem dyslokacji z odpowiednimi organami władzy na Ukrainie (art. 15, ust 5). Strony przewidziały także okres stacjonowania rosyjskiej Floty Czarnomorskiej na terytorium Ukrainy, który wynosił 20 lat od momentu podpisania porozumienia (art. 25) ${ }^{31}$. W kwietniu 2010 roku prezydent Ukrainy Wiktor Janukowycz podpisał z Rosją tzw. porozumienie charkowskie, przedłużające ten okres do 2042 roku. Po aneksji Krymu Rosja w trybie jednostronnym wypowiedziała powyższe porozumienie. Zatem zgodnie z prawem międzynarodowym po 2017 roku Flota Czarnomorska przebywa na okupowanym terytorium Ukrainy nielegalnie.

Federacja Rosyjska wykorzystała swoje jednostki regularne i okręty Floty Czarnomorskiej do blokady portów i wybrzeża Krymu, części terytorium państwa ukraińskiego (art. 3 pkt c definicji). Przed rosyjską inwazją na Krymie jednostki Sił Morskich Ukrainy na półwyspie posiadały 3 bazy stacjonowania okrętów: a) Zatoka Sewastopolska (Północ) $)^{32}$, b) Zatoka Strzelecka (Sewastopol) ${ }^{33}$ i c) Południowa Baza Sił Morskich

30 «Самооборона» Криму: їх знають в обличчя, https://ua.krymr.com/a/samooborona-krymu-ih-znaiut-v-oblychchia/29492740.html, inf. 20.08.2019.

31 Соглашение между Российской Федерацией и Украиной о статусе и условиях пребывания Черноморского флота Российской Федераиии на территории Украины от 28 мая 1997 г., [w:] Россия-Украина 1990-2000. Документы и материаль, т. 2, Москва 2001, с. 125-133.

32 Stacjonowały: Korweta „Tarnopol”, okręt dowodzenia „Sławutycz”, okręty wspomagania „Koreć” i „Krasnoperekopśk”.

33 Stacjonowały: łódź podwodna "Zaporoże”, korweta rakietowa „Prydniprowja”, kuter rakietowy „Pryłuky”, korwety „Łuck” i „Chmielnicki”, okręt dowodzenia „Donbas”, okręty wspomagania 
(jezioro Donuzław) ${ }^{34}$. Łącznie stacjonowało w nich 17 okrętów bojowych i 20 okrętów i kutrów wspomagania. Ponadto Siły Morskie Ukrainy posiadały na półwyspie 30 bojowych samolotów i helikopterów, 40 czołgów, 280 bojowych wozów opancerzonych oraz 60 systemów artyleryjskich i moździerzy ${ }^{35}$. W wyniku agresji na Półwyspie Krymskim Rosja zablokowała i zajęła większą część okrętów ukraińskiej marynarki wojennej.

28 lutego 2014 roku okręty Floty Czarnomorskiej FR zablokowały morskie oddziały Straży Granicznej Ukrainy w zatoce Bałakława. W dniach 3-27 marca tegoż roku początkowo okręt flagowy Floty Czarnomorskiej, krążownik rakietowy „Moskwa”, mały okręt rakietowy „Sztil” i okręt wspomagania „СФП-183” zablokowały wyjście ukraińskim okrętom z zalewu Donuzław, a następnie w tym celu zatopiono wysłużony dużej klasy rosyjski niszczyciel „Oczakow” i małe okręty wspomagania. W tym samym czasie okręty Floty Czarnomorskiej przystąpiły także do blokady najbardziej wartościowych okrętów ukraińskiej marynarki, stacjonujących w Zatoce Sewastopolskiej. Brytyjska grupa konsultingowa ds. obronności IHS Jane’s na podstawie zdjęć satelitarnych francuskiej organizacji (CNES) doszła do wniosku, że rosyjskie okręty uniemożliwiły ukraińskim jednostkom pływającym opuszczenie portu. W operacji blokowania okrętów państwa ukraińskiego Rosja wykorzystała 2 holowniki, 1 trałowiec, a także okręty rakietowe: krążownik „Moskwa”, patrolowiec „Smietliwy” i poduszkowiec „Samum”36.

Ponadto okręty oraz żołnierze rosyjskiej floty nie ograniczyły się jedynie do biernego blokowania ukraińskich okrętów, ale podjęły działania uniemożliwiające ostatnim wypłynięcie na otwarte morze. Jako przykład możemy przytoczyć działania z 3 marca rosyjskich sił wobec okrętu dowodzenia „Sławutycz” i korwety „Tarnopol”. Po przeprowadzeniu tzw. referendum krymskiego Rosja przeważnie siłą przejęła większość jednostek Sił Morskich Ukrainy. Przeciwstawieniem się wrogiemu przejęciu szczególnie wsławiła się załoga trałowca „Czerkasy”, który podjął kilka nieudanych prób wydostania się z blokady oraz skutecznie do 25 marca odpierał ataki rosyjskich jednostek specjalnych $^{37}$.

Ukraiński badacz Wład Kostrow zauważył, że oprócz rosyjskiej agresji odpowiedzialność za poniesione straty spada także na ówczesnego ministra obrony Ukrainy admirała Igora Teniucha, który odmówił wydania rozkazu ukraińskim okrętom wy-

„Skwyra”, „Kremeneć”, „Iziasław”, „Dżankoj”, „Sudak”, „Bachmacz”, „Fastów”, „Bałta”, „Siewierodonećk”, „Szostka”, „Zołotonosza”, „Dubny” oraz kilka kutrów.

34 Stacjonowały: korweta „Winnica”, trałowce „Czernigów”, „Czerkasy”, „Genicześk”, duży okręt desantowy „Konstantyn Olszanśkyj”, średni okręt desantowy „Kirowograd”, a także okręty i kutry wspomagania „Jewpatoria”, „Horłiwka”, „Kowel”, „Teodozja”, „Chersoń”, „Nowoozerne”, „Welyka Ołęksandriwka".

35 В. Костров, Хроніка кримського протистояння, «Віче» 2014, № 7, http://www.viche.info/ journal/4145/, inf. 15.07.2019.

36 Ł. Wojnicki, Tak wyglada blokada Krymu przez Rosjan na satelitarnych mapach, http://wyborcza. pl/1,75399,15588138,Tak_wyglada_blokada_Krymu_przez_Rosjan_na_satelitarnych.html, inf. 12.06.2019.

37 В. Костров, op. cit. 
płynięcia w morze celem uniknięcia rosyjskiej blokady ${ }^{38}$. Brzemienna w skutkach decyzja ministra oraz zdrada wielu wyższych rangą oficerów, w tym nowego dowódcy marynarki wojennej Ukrainy Denisa Berezowskiego ${ }^{39}$, przesądziły o utracie większości okrętów zablokowanych i zdobytych siłą przez rosyjskie jednostki specjalne wspierane przez odziały tzw. krymskiej samoobrony. Jednak błędy i zaniedbania strony ukraińskiej dotyczące obrony swojego terytorium nie zmieniają kwalifikacji działań strony rosyjskiej.

24 marca 2014 roku Ukraina rozpoczęła proces wycofania swoich jednostek z okupowanego półwyspu, nazwany oficjalnie zmianą miejsca dyslokacji. W tej sprawie porozumiały się dowódcy sztabów generalnych obydwu państw. Jednak 16 czerwca Rosja jednostronnie wstrzymała proces przekazania zajętego uzbrojenia, tłumacząc swoją decyzję wybuchem konfliktu na Donbasie. Jeszcze przed rozpoczęciem tego procesu ukraińskim wojskowym udało się wyprowadzić z Krymu 9 samolotów i helikopterów należących do lotnictwa morskiego (Mi14, K27PL, An-26, Be-12). Z kolei do połowy czerwca Rosja przekazała Ukrainie 35 okrętów i kutrów, zatrzymując najbardziej wartościowe okręty bojowe (1 łódź podwodną, 4 korwety, 2 trałowce, 1 duży okręt desantowy i 1 okręt dowodzenia $)^{40}$ oraz kilkanaście okrętów pomocniczych. Ukraina straciła także ok. 75\% składu osobowego Sił Morskich ${ }^{41}$, część żołnierzy i marynarzy, łamiąc przysięgę, zaciągnęła się do Sił Zbrojnych $\mathrm{FR}^{42}$, natomiast druga część zwolniła się ze służby.

38 Ibidem.

39 Kontradmirał Denis Berezowski, łamiąc przysięgę, przeszedł na służbę Federacji Rosyjskiej. 2 marca 2014 r. został mianowany przez samozwańcze władze Krymu dowódcą marynarki wojennej półwyspu, a 20 kwietnia prezydent Rosji mianował D. Berezowskiego zastępcą dowódcy rosyjskiej Floty Czarnomorskiej. Podobnie uczynił Siergiej Jelisiejew, były zastępca dowódcy Sił Morskich Ukrainy i dowódca Garnizonu Sewastopolskiego, który otrzymał od W. Putina nominację na zastępcę dowódcy rosyjskiej Floty Bałtyckiej.

40 Rosja w dalszym ciągu przytrzymuje: okręt dowodzenia "Sławutycz”, okręt podwodny „Zaporoże”, korwety „Łuck”, „Tarnopol”, „Pridnieprowje” i „Chmielnicki”, a także trałowce „Czerkasy” i „Czernihow” oraz duży okręt desantowy „Konstantyn Olszański”. Виведення українських кораблів з Криму призупиняється, http://wartime.org.ua/11369-vivedennya-ukrayinskih-korablv-z-krimuprizupinyayetsya-zm.html.

41 Модель та ребормування Військово-Морських Сил Збройних Сил України (2015-2020), http:// defense-ua.com/rus/hotnews/?id=45421, inf. 21.05.2019.

${ }^{42}$ Oprócz dowódcy Sił Morskich Ukrainy kontradmirała Denisa Berezowskiego prokuratura wojskowa oskarżyła o zdradę pułkownika S. Storożenke, dowódcę 36. oddzielnej brygady obrony wybrzeża, pułkownika D. Kozaczenko, dowódcę 406. oddzielnej grupy artylerii brzegowej Wojsk Obrony Wybrzeża, a także komandorów D. Kłoczana, dowódcę okrętu podwodnego „Zaporoże”, S. Makiejewa, dowódcę korwety „Łuck”, M. Jemieljanenkowa, dowódcę korwety „Tarnopol”, O. Żurkina, dowódcę korwety rakietowej „Prydniprowja”, S. Zaugolnikowa, dowódcę korwety „Winnica”, B. Palija, dowódcę trałowca „Czernihiw”, W. Chrodczenko, dowódcę średniego okrętu desantowego „Kirowograd”, A. Bariejewa, dowódcę okrętu dowodzenia „Donbas”, D. Suchara, dowódcę korwety rakietowej „Pryłuky” i wiele innych wysokiej rangi dowódców. Zob. Wojskowa Prokuratura Południowego Okręgu Ukrainy, http://www.vppdr.gp.gov.ua/ua/news.html?fp=10, inf. 20.02.2016. 
Ponadto 19 marca 2014 roku przy pomocy okrętów Floty Czarnomorskiej oraz jednostek specjalnych Sił Zbrojnych FR zostały w sposób siłowy zajęte w rejonie złoża odeskiego (jest usytuowane bliżej Odessy aniżeli Krymu) dwie morskie platformy wiertnicze należące do spółki „Czornomornaftohaz” (100\% akcji NAK „Naftohaz Ukrainy”). Zaznaczmy, że wrogie przejęcie miało miejsce w wodach terytorialnych Ukrainy, co umożliwia Rosji nielegalne wydobycie rocznie ponad $2 \mathrm{mld}^{3}$ ukraińskiego gazu. $\mathrm{W}$ grudniu 2015 roku okręty FSB i Floty Czarnomorskiej eskortowały odholowanie platform wiertniczych bliżej Krymu, uniemożliwiając stronie ukraińskiej zbliżenie się do rejonu wydobywania gazu (okręt wspomagania „Netiszyn”). W tym rejonie sporadycznie dochodzi do incydentów, w trakcie których jednostki rosyjskie (GRU i piechoty morskiej) dwukrotnie w 2017 roku ostrzelały jednostki ukraińskie, najpierw okręt wspomagania „Poczajiw”, a następnie samolot transportowy SZ Ukrainy (An-26) ${ }^{43}$.

Według danych międzynarodowej organizacji pozarządowej C4ADS, monitorującej od 2016 roku działania Rosji w zakresie zakłóceń pracy systemu GPS/GNSS, odnotowano ponad 9 tys. przypadków tego typu działań ze strony Federacji Rosyjskiej wobec statków państw trzecich, w tym na morzach Czarnym i Azowskim, szczególnie w rejonie Sewastopola i Kerczu ${ }^{44}$. Powyższe działania zagrażają bezpieczeństwu żeglugi morskiej w rejonie Krymu i Cieśniny Kerczeńskiej. Ponadto Rosja nielegalnie wydobywa piasek w odległości $14 \mathrm{~km}$ od wyspy Dżaryłgacz niedaleko Skadowska w wodach terytorialnych Ukrainy. Proceder osłaniają okręty ochrony wybrzeża Federalnej Służby Bezpieczeństwa $\mathrm{FR}^{45}$.

Powyższe fakty dobitnie podkreślają, że agresja Rosji wobec Ukrainy doprowadziła do międzynarodowego konfliktu zbrojnego. Zatem sytuację Autonomicznej Republiki Krymu (Ukraina) należy rozpatrywać w kontekście Konwencji Genewskiej z 1949 roku jako terytorium okupowanego. Z punktu widzenia zarówno Ukrainy, jak i Federacji Rosyjskiej jest to suwerenne terytorium ich państwa. Rosja nie uznaje swojej okupacji Półwyspu Krymskiego i Miasta Sewastopol, zaś akcentuje fakt „przyłączenia” Krymu do Rosji dnia 18 marca 2014 roku. Uznając Krym za swoją integralną część, FR odrzuca możliwość stosowania w tym przypadku Konwencji Genewskiej. Z kolei Ukraina nie uznaje zmiany statusu prawnego Autonomicznej Republiki Krymu i Miasta Sewastopola, uważając ww. terytorium za integralną część swojego państwa, które w wyniku agresji Federacji Rosyjskiej zostało okupowane. W jednym i drugim przypadku państwa podjęly stosowne wewnętrzne kroki legislacyjne, które dotyczą nie tylko granicy lądowej, ale także wód terytorialnych i wyłącznej strefy ekonomicznej ${ }^{46}$.

43 «Вишки Бойка» знайшли по треках буксирів і фото військовослужбовців РФ, https://informnapalm.org/ua/vyshky-bojka-znajshly-po-trekah-buksyriv-i-foto-vijskovosluzhbovtsiv-rf/, inf. 20.06.2019.

44 ABOVE US ONLY STARS, https://www.c4reports.org/aboveusonlystars, inf. 18.05.2019.

45 Росія продовжує незаконний видобуток піску поблизу Джарилгача, https://mil.in.ua/rosiya-prodovzhuye-nezakonnyj-vydobutok-pisku-poblyzu-dzharylgacha/, inf. 15.06.2019.

46 О. Марусяк, Анексія Криму Російською Федерацією як злочин агресії проти Украйни: міжнародно-правові аспекти, Чернівці 2016, с. 130-143. 
W zdecydowanej większości społeczność międzynarodowa nie poparła rosyjskiej aneksji Krymu. Świadczy o tym głosowanie w Organizacji Narodów Zjednoczonych 27 marca 2014 roku w sprawie Rezolucji ZO ONZ (68/262 „Integralność terytorialna Ukrainy"). Ze 169 państw członkowskich 100 poparło korzystny dla Ukrainy dokument, w tym Polska. Natomiast 58 państw wstrzymało się od głosu, a stanowisko Rosji uzyskało przychylność zaledwie 11 członków organizacji ${ }^{47}$. Zatem jedynie 11 państw uznaje rosyjską jurysdykcję nad Krymem, podczas gdy zdecydowana większość poparła integralność terytorialną Ukrainy w granicach uznanych przez społeczność międzynarodową. W uchwalonej rezolucji ZO ONZ podkreślono, że przeprowadzenie referendum w Autonomicznej Republice Krymu było niezgodne z prawem i nie ma mocy wiążącej, dlatego też nie posiada skutków prawnych w zakresie statusu Krymu i Sewastopola ${ }^{48}$. Poza prawem do „interwencji humanitarnej” kolejnym argumentem strony rosyjskiej jest prawo "narodu krymskiego" do samostanowienia (prawo do secesji). Jednak ten punkt widzenia również nie wytrzymuje krytyki. Po pierwsze, prawo do samostanowienia nie ma bezpośredniego zastosowania i nie może być realizowane ze szkodą dla integralności terytorialnej państw. Po drugie, w ARK doszło do przewrotu, a „referendum” rozpisano i przeprowadzono niezgodnie z ukraińskim ustawodawstwem. Po trzecie, „referendum” przeprowadzono w warunkach agresji i okupacji strony zainteresowanej (Rosji).

Dokonawszy aneksji Krymu, strona rosyjska również bezprawnie rozpoczęła budowę Mostu Kerczeńskiego (Most Krymski), łączącego okupowany półwysep z terytorium FR. Kwestia budowy mostu, mającego dla Rosji znaczenie strategiczne, była omawiana w rosyjsko-ukraińskich rozmowach bilateralnych, począwszy od $2006 \mathrm{roku}$, kiedy na Ukrainie po wyborach parlamentarnych powstał koalicyjny rząd Wiktora Janukowycza. Jednak porozumienie $\mathrm{w}$ tej sprawie na szczeblu rządowym strony podpisały dopiero w grudniu 2013 roku, kiedy prezydent Wiktor Janukowycz zrezygnował z podpisania umowy stowarzyszeniowej z UE i rozpoczął zacieśnianie relacji z Rosją. Zmiana władzy na Ukrainie oraz rosyjska aneksja Krymu spowodowały wycofanie się nowego rządu w Kijowie z niniejszego porozumienia (1.10.2014). Budowa Mostu Kerczeńskiego przez Federację Rosyjską stanowiła kolejne pogwałcenie norm prawa międzynarodowego. $Z$ tego tytułu wobec firm i osób fizycznych związanych $\mathrm{z}$ tą nielegalną inwestycją Ukraina, USA, UE i niektóre państwa wprowadziły sankcje ${ }^{49}$.

16 września 2016 roku Ukraina złożyła wniosek do Międzynarodowego Trybunału Sprawiedliwości ONZ w Hadze, oskarżając Rosję o naruszenie Konwencji ONZ o Prawie Morza, wnioskując o potwierdzenie suwerennych praw Ukrainy w wodach Morza

${ }^{47}$ Ibidem.

48 Резолюиия, принятая Генеральной Ассамблеей 27 марта 2014 года (68/262. Территориальная иелостность Украины), http://daccess-dds-ny.un.org/doc/UNDOC/GEN/N13/455/19/PDF/ N1345519.pdf?OpenElement, inf. 25.08.2014.

49 Т. Короткий, Н. Хендель, Міжнародно-правовий аналіз ситуації в Азовському морі та Керченській протоиі, «Український часопис міжнародного права» 2018, № 2, s. 46-47. 
Czarnego i Azowskiego oraz Cieśninie Kerczeńskiej ${ }^{50}$. Z kolei 16 kwietnia 2019 roku MSZ Ukrainy skierowało do Międzynarodowego Trybunału Prawa Morza wniosek o podjęcie działań wobec Rosji zmuszających ją do uwolnienia ukraińskich marynarzy oraz zwrotu zajętych okrętów ${ }^{51}$. Stały Trybunał Arbitrażowy MTS wyznaczył termin rozpatrywania skargi Ukraina przeciwko Rosji na 10-15 czerwca 2019 roku.

Powyższe nie pozostawia żadnych wątpliwości, że Rosja, anektując i okupując Krym, złamała normy prawa międzynarodowego, 407 umów bilateralnych oraz 80 umów międzynarodowych z Ukrainą. Federacja Rosyjska rości sobie prawo do Krymu i Cieśniny Kerczeńskiej, ale prawo nie rodzi się z bezprawia (ex injuria jus non oritur). Z tego względu tzw. incydent w Cieśninie Kerczeńskiej nie może być traktowany jako obrona integralności terytorialnej Rosji, lecz jest aktem agresji i kontynuacją agresywnej polityki wobec Ukrainy.

Według definicji profesora M. Szumiłowa, rosyjsko-ukraiński konflikt o Krym należy rozpatrywać jako międzynarodowy konflikt zbrojny. Większość rosyjskich badaczy pisze o wojnie domowej na Ukrainie oraz secesji $\mathrm{Krymu}^{52}$. Do nielicznego grona rosyjskich naukowców mających odmienne zdanie należy wykładowca z Moskwy (MGIMO) Walery Sołowiej, który uważa, że stosunki pomiędzy Rosją a Ukrainą nie można scharakteryzować inaczej aniżeli jako trudny i intensywny konflikt międzypaństwowy $^{53}$. W tym kontekście należy przytoczyć opinię znanej organizacji „Memoriał”, która w odniesieniu do sytuacji we wschodnich regionach Ukrainy jednoznacznie stwierdziła, że do momentu wtargnięcia jednostek regularnych FR w sierpniu $2014 \mathrm{r}$. na ukraińskie terytorium w obwodach ługańskim i donieckim możemy mówić o konflikcie niskiej intensywności, natomiast agresja i działania militarne FR przesądzają o określaniu tego konfliktu jako międzynarodowego konfliktu zbrojnego ${ }^{54}$. Badacze ukraińscy piszą natomiast o wojnie Rosji wobec Ukrainy ${ }^{55}$, agresji i aneksji Krymu

50 У Гаазі призначили дату суду щодо порушень Росією морського права, https://mil.in.ua/u-gaazi-pryznachyly-datu-sudu-shhodo-porushen-rosiyeyu-morskogo-prava/, inf. 23.07.2019.

51 Ministerstwo Spraw Zagranicznych Ukrainy, https://mfa.gov.ua/ua/press-center/news/71884-zajavaministerstva-zakordonnih-sprav-ukrajini-shhodo-jogo-zvernennya-do-mizhnarodnogo-tribunaluz-morsykogo-prava-z-privodu-negajnogo-zvilynennya-tryoh-ukrajinsykih-vijsykovo-morsykih-su den-ta-dvadcyati-chotiryoh-chleniv-jihnih-jekipazhiv, inf. 19.07.2019.

52 К.П. Саврыга, Украинский кризис и международное право: конфликт на востоке Украинь и сеи,ессия Крыма, „Право и политика” 2015, № 7; И.И. Котляров, Ю.В. Пузырева, Гражданская война в Украине: международное право и уголовная ответственность индивидов за совершение международных преступлений, „Московский журнал международного права” 2014, № 4; Е Александрова, Сецесия Крыма: поиск новой нормативной теории права на сецесию, «Правовая инициатива» 2015, № 1.

53 В. Соловей, op. cit.

54 Доклад «Между перемирием и войной», Правозащитный центр «Мемориал», https://memohrc. org/sites/all/themes/memo/templates/pdf.php?pdf=/sites/default/files/old/files/1658.pdf, inf. 15.12.2019.

55 Г. Перепелиця, Україна-Росія. Війна в умовах співіснування, Київ 2015. 
z pogwałceniem prawa ukraińskiego i międzynarodowego ${ }^{56}$. Polscy uczeni i eksperci, opisując problem, posługują się najczęściej pojęciem konfliktu rosyjsko-ukraińskiego ${ }^{57}$. Niewielu badaczy podważa także kwalifikacje czynu ze strony Rosji jako aneksję. Opisując politykę Rosji wobec Ukrainy, Maciej Raś stwierdził, że FR nie tylko anektowała Autonomiczną Republikę Krymu oraz Sewastopol, ale wsparła także działania separatystyczne i destabilizujące w innych częściach Ukrainy ${ }^{58}$.

Profesor Stanisław Bieleń, znawca rosyjskiej Realpolitik, zauważył, że: „Aneksja Krymu była niewątpliwie naruszeniem prawa międzynarodowego, ale była też oparta na przesłankach wolicjonalnych ludności krymskiej. Do aneksji doszło drogą faktów dokonanych, które mają charakter normatywny"59. Powyżej wskazano już, że do aneksji Krymu doszło w wyniku zbrojnej agresji Rosji wobec Ukrainy, zorganizowania przewrotu w Autonomicznej Republice Krymu, przeprowadzenia przez nielegalne władze półwyspu niezgodnie z ukraińskim ustawodawstwem wspólnie z rosyjską władzą okupacyjną „referendum”, wyniki którego nie zostały uznane przez społeczność międzynarodową. Na domiar wszystkiego wyniki „referendum” zostały sfałszowane ${ }^{60}$. Zatem nie możemy mówić o tym, że decyzja zależała tylko od woli ludności krymskiej. Oczekiwanie od Rosji pod rządami Władimira Putina, która stała się państwem twardego autorytaryzmu oraz umiejętnie „zarządza” procesem wyborczym we własnym kraju, swobodnego i demokratycznego przeprowadzenia referendum ${ }^{61}$ jest nieporozumieniem. Metodą faktów dokonanych Rosja okupowała Krym, co pozwala jej sprawować nad nim kontrolę, lecz aneksja nie została uznana przez społeczność międzynarodową, która stara się przestrzegać zasady „prawo nie rodzi się z bezprawia”. Z powodu bez-

56 О. Задорожній, Анексія Криму - міжнародний злочин, Київ 2015 (O. Zadorozhnii, Russian doctrine of international law after the annexation of Crimea: Monograph, Kуiv 2016); О. Марусяк, Анексія Криму Російською Федерачією як злочин агресії проти України: міжнародно-правові аспекти, Чернівці 2016.

57 M. Lakomy, Przebieg i uwarunkowania konfliktu na Ukrainie, [w:] Implikacja konfliktu ukraińskiego dla polityki zagranicznej i bezpieczeństwa Polski. Aspekty polityczne, wojskowe, gospodarcze oraz społeczne, red. K. Czornik, M. Lakomy, M. Stolarczyk, Katowice 2015, s. 14 i n.

58 M. Raś, Polityka Rosji wobec Ukrainy i jej implikacje dla ładu międzynarodowego w Europie, [w:] ibidem, s. 111.

59 S. Bieleń, Powrót do Realpolitik w stosunkach Rosji z Zachodem jako konsekwencja konfliktu na Ukrainie, [w:] ibidem, s. 397.

60 Математика и референдум по Крыму, https://trv-science.ru/2014/03/25/matematika-ireferendum-po-krymu/, inf. 14.12.2019.

${ }^{61}$ Według danych separatystów w tzw. referendum wzięło udział $83 \%$ uprawnionych, zaś za przyłączeniem Krymu do Rosji opowiedziało się 97\% głosujących. Jednak w sprawozdaniu Rady ds. Społeczeństwa Obywatelskiego i Praw Człowieka przy Prezydencie FR ujawniono rzeczywiste dane mówiące o frekwencji na poziomie 30-50\% oraz 50-60\% głosujących za przyłączeniem Półwyspu Krymskiego do Rosji. Результаты общекрымского референдума, http://www.rada.crimea.ua/ referendum/resultaty; Совет при Путине поставил под сомнение результаты крымского реберендума, http://www.stopfake.org/sovet-pri-putine-postavil-pod-somnenie-rezultaty-krymskogoreferenduma/, inf. 5.07.2019. 
prawnej aneksji Krymu wobec Rosji wprowadzono także sankcje ${ }^{62}$. Ponadto enigmatycznie i dziwnie brzmi odwoływanie się do przesłanek wolicjonalnych, a nie do zasady samostanowienia. Mieszkańcy Krymu zrealizowali swoje prawo do samostanowienia, uzyskując w 1991 roku status autonomii. W Deklaracji zasad prawa międzynarodowego z 1970 roku czytamy, że realizowanie tego prawa nie powinno być interpretowane jako upoważniające lub zachęcające do działań godzących w integralność terytorialną lub jedność polityczną suwerennych i niepodległych państw, postępujących zgodnie $\mathrm{z}$ zasadą równouprawnienia i samostanowienia ${ }^{63}$.

Z kolei profesor Ryszard Zięba tzw. kryzys ukraiński nazywa przejawem ostrej rywalizacji pomiędzy Rosją a Zachodem, a przede wszystkim między USA a Rosją o wpływy na Ukrainie. Szczególnym, podwójnym dnem tego kryzysu jest konflikt między Rosją a Ukrainą, w którym ta ostatnia utraciła Krym i jest stroną poszkodowaną ${ }^{64}$. Nie ulega wątpliwości, że międzypaństwowy konflikt rosyjsko-ukraiński wykracza poza ramy konfliktu bilateralnego, stanowiąc ważny element rywalizacji Rosji z Zachodem. Prowadząc agresywne działania wobec Ukrainy na etapie tzw. kryzysu krymskiego i wojny donbaskiej, Federacja Rosyjska wykorzystywała wewnętrzne uwarunkowania państwa ukraińskiego (podziały regionalne i wyznaniowe, rywalizacje grup oligarchicznych, dysfunkcyjność struktur państwowych). Jednak uwarunkowania wewnętrzne i międzynarodowe stanowią jedynie tło do konfliktu pomiędzy dwoma sąsiednimi państwami. Niezależne i suwerenne państwo ukraińskie, znajdujące się w orbicie wpływów zachodnich, kładzie kres rosyjskim marzeniom o potędze imperialnej.

Autor podziela podejście rosyjskiego „Memoriału” i innych organizacji zajmujących się prawami człowieka (Amnesty International i Human Rights Watch), które jednoznacznie stwierdzają, iż mamy do czynienia z rosyjsko-ukraińskim międzynarodowym konfliktem zbrojnym, co implikuje stosowanie międzynarodowego prawa humanitarnego. Zbliżone stanowisko reprezentują Paweł Ochman i Jakub Wojas, pisząc o tzw. kryzysie krymskim, kwalifikują działania Rosji jako akt agresji z użyciem Sił Zbrojnych FR. Opisując tzw. wojnę na Ukrainie, eksperci wskazują na konflikt zbrojny pomiędzy Rosją a Ukrainą, składający się z dwóch faz (krymskiej i donbaskiej). Przy czym w interesie Rosji jest podział tego konfliktu na dwa odrębne. Po pierwsze, w trakcie pierwszej fazy Rosja przyznała fakt użycia swoich sił zbrojnych. Natomiast w trakcie drugiej fazy podjęła działania podprogowe, zaprzeczając swojej obecności na Donbasie. Z kolei Ukraina, nie podejmując działań militarnych w ramach natychmiastowej odpowiedzi na rosyjską agresję na Krymie, w przypadku uznania tego konfliktu za odrębny, straciłaby prawo do proporcjonalnego użycia siły w swojej obronie. W sytuacji różnych faz tego samego trwającego konfliktu zbrojnego Ukraina zachowuje prawo do

${ }_{62}$ Zob. Sankcje i Rosja, red. J. Ćwiek-Karpowicz, S. Secrieru, Warszawa 2015.

63 Deklaracja zasad prawa międzynarodowego dotyczących przyjaznych stosunków i współdziałania państw zgodnie z Kartą Narodów Zjednoczonych, przyjęta na podstawie Rezolucji Zgromadzenia Ogólnego 2625(XXV), 24 października $1970 \mathrm{r}$.

64 R. Zięba, Międzynarodowe implikacje kryzysu ukraińskiego „Stosunki Międzynarodowe - International Relations" 2014, nr 2, s. 15. 
obrony ${ }^{65}$ W naszej ocenie agresja w Cieśninie Kerczeńskiej jest trzecią fazą rosyjsko-ukraińskiego konfliktu zbrojnego (działania na morzu) ${ }^{66}$.

Rosja zaprzecza, że jest stroną międzynarodowego konfliktu zbrojnego. W interesach Kremla jest jego przedstawianie jako wojny hybrydowej bądź konfliktu niskiej intensywności o implikacjach międzynarodowych, co pozwoli Rosji na unikanie odpowiedzialności. Wydarzenia na Ukrainie nazywane są często „kryzysem ukraińskim” bądź „,konfliktem zbrojnym na Ukrainie”. Jednak nie wpisują się one w klasyczny model konfliktu wewnętrznego, w tym wojny domowej z kilku powodów. Po pierwsze, jedną z podstawowych przyczyn konfliktu był geopolityczny wybór Ukrainy. W tej kwestii decydujące znaczenie miała rywalizacja między NATO i UE a Federacją Rosyjską o strefy wpływu w nowej Europie Wschodniej. Postulaty integracji europejskiej Ukrainy w latach 2010-2013 jednoczyły większą część elity ukraińskiej oraz były realizowane przez prorosyjską Partię Regionów, reprezentującą przeważnie mieszkańców południowych i wschodnich obwodów. Po drugie, początków „kryzysu ukraińskiego” należy upatrywać już w wojnie handlowej i informacyjnej, którą Rosja rozpoczęła w połowie 2013 roku celem powstrzymania Ukrainy przed podpisaniem Umowy stowarzyszeniowej z UE. „Euromajdan” był odpowiedzią na gwałtowną zmianę przez prezydenta Wiktora Janukowycza głównego priorytetu w polityce zagranicznej Ukrainy, który znaczna część społeczeństwa traktowała w kategoriach wyboru cywilizacyjnego. Po trzecie, bezpośredni zorganizowani uczestnicy konfliktu nie pochodzą z jednego państwa, pomimo że działania zbrojne i terrorystyczne są prowadzone w kilku obwodach Ukrainy. Po czwarte, zewnętrzny, a nie wewnętrzny czynnik rosyjski odegrał kluczową rolę w trakcie „ruskiej wiosny” i powstania tzw. Donieckiej i Ługańskiej Republik Ludowych. Po piąte, w gronie pośrednich uczestników „kryzysu ukraińskiego” z jednej strony znajdują się USA i UE, a z drugiej Federacja Rosyjska, która bierze także bezpośredni udział zbrojny w konflikcie. Po szóste, aneksja Krymu, destabilizacja Donbasu przy użyciu Sił Zbrojnych FR stawia Rosję w roli strony konfliktu rosyjsko-ukraińskiego.

Zatem w przypadku Krymu i Donbasu nie mamy do czynienia z dwoma różnymi konfliktami, lecz z poszczególnymi etapami tego samego konfliktu. Pomimo iż Kreml stara się zaprzeczać swojemu udziałowi w konflikcie na wschodzie Ukrainy, to istnieje bardzo dużo dowodów, że Rosja w ramach kontynuowania polityki destabilizacji Ukrainy wywołała ten konflikt oraz bierze w nim aktywny udział, sprawując pełną i efektywną kontrolę nad rebeliantami.

Uwzględniając powyższe, możemy wyodrębnić następujące etapy konfliktu rosyjsko-ukraińskiego: 1) presja handlowa, dyplomatyczna i informacyjna Rosji wobec Ukrainy (sierpień 2013 - listopad 2013), 2) zablokowanie przez Rosję podpisania przez Ukrainę umowy stowarzyszeniowej z UE oraz wewnętrzny wymiar konfrontacji na

${ }^{65}$ P. Ochman, J. Wojas, Współczesne znaczenie aktu wypowiedzenia wojny - uwagi w kontekście konfliktu na wschodzie Ukrainy, „Bezpieczeństwo. Teoria i praktyka” 2015, nr 3, s. 87.

66 Zob. J. Wojas, Incydent w Cieśninie Kerczeńskiej w świetle prawa międzynarodowego, „Sprawy Międzynarodowe" 2019, nr 2. 
Ukrainie (listopad 2013 - luty 2014), 3) agresja i aneksja Krymu (luty 2014 - marzec 2014), 4) „ruska wiosna” i operacja antyterrorystyczna na Ukrainie przeciwko rosyjskim jednostkom nieregularnym (kwiecień 2014 - lipiec 2014), 5) aktywna faza konfliktu zbrojnego $\mathrm{z}$ udziałem rosyjskich oddziałów regularnych bez znaków rozpoznania (sierpień 2014 - luty 2015), 6) wojna pozycyjna oraz próby narzucenia Ukrainie przez Rosję warunków uregulowania konfliktu (luty 2015 - 2018), 7) pełzająca aneksja Morza Azowskiego i Cieśniny Kerczeńskiej (2016 - grudzień 2018).

\section{Agresywne działania FR na Morzu Azowskim i w Cieśninie Kerczeńskiej}

Eksperci i znawcy prawa morskiego przewidywali, że wcześniej czy później na Morzu Azowskim, zwłaszcza w Cieśninie Kerczeńskiej dojdzie do konfliktu pomiędzy Rosją a Ukrainą, którego źródłem będzie bezprawna aneksja Autonomicznej Republiki Krymu. Rosja a priori uznała Krym i wody terytorialne wokół półwyspu (12 Mm) za swoje, roszcząc sobie prawa do wyłącznej strefy ekonomicznej (do $200 \mathrm{Mm}$ ). Ukraina nie zgadza się z bezprawnym działaniem Rosji na lądzie i na morzu ${ }^{67}$, mając wsparcie wspólnoty międzynarodowej.

Sytuację w regionie zaogniła nielegalna budowa i pompatyczne otwarcie w maju 2018 roku Mostu Kerczeńskiego (Krymskiego) przez Rosję. Otwarcie przeprawy potępiły zarówno Ukraina, jak i Stany Zjednoczone oraz UE, uznając jego budowę za pogwałcenie integralności terytorialnej Ukrainy oraz naruszenie prawa międzynarodowego. Wobec firm biorących udział w nielegalnej inwestycji wprowadzono sankcje. USA uczyniły to jeszcze we wrześniu 2016 roku, natomiast UE dopiero w lipcu 2018 roku.

Od tego momentu Rosja przystąpiła do wzmocnienia swojej aktywności na Morzu Azowskim. Zdaniem polskiego analityka Michała Marka, zwiększając swoją obecność wojskową na Morzu Azowskim, Rosja dążyła do „odcięcia” Ukrainy od tego akwenu i spowodowania strat dla ukraińskiej gospodarki. W okresie między majem a lipcem 2018 roku na Morzu Azowskim pojawiło się 18 dodatkowych okrętów wojennych, ściągniętych m.in. z Morza Kaspijskiego. W sumie strona rosyjska posiadała w tym akwenie zgrupowanie składające się z ok. 40 okrętów Służby Granicznej FSB oraz marynarki wojennej, w tym kutrów artyleryjskich (typu „Gryf” i „Trzmiel”) oraz nowoczesnych okrętów rakietowych typu „Bujan-M”, uzbrojonych m.in. w rakiety „Kalibr”68.

Agresywne działania należy interpretować jako próbę przetworzenia Morza Azowskiego na wewnętrzny akwen Federacji Rosyjskiej. Powyższe potwierdza nie tylko wzmocnienie zgrupowania jednostek Sił Morskich Rosji w akwenie, ale także wzmożone kontrole statków handlowych zmierzających do ukraińskich portów w Berdiańsku i Mariupolu. Przed 2014 rokiem czas przeprowadzania przez FSB kontroli zatrzyma-

67 M. Dura, Kryzys na Morzu Azowskim. „Nieważne kto ma racje, ważne kto ma rakiety”, https:// www.defence24.pl/kryzys-na-morzu-azowskim-nie-wazne-kto-ma-racje-wazne-kto-ma-rakiety, inf. 12.05.2019.

68 M. Marek, Militaryzacja Morza Azowskiego - rosyjskie uderzenie w gospodarkę Ukrainy, https://www. defence24.pl/militaryzacja-morza-azowskiego--rosyjskie-uderzenie-w-gospodarke-ukrainy-analiza, inf. 18.05.2019. 
nych statków wynosił średnio ok. 2 godzin. Natomiast w analizowanym okresie wzrósł nawet do 88 godzin $^{69}$. Strona rosyjska oczywiście zaprzecza faktom blokowania ukraińskich portów, natomiast dane mówią same za siebie. Zdaniem rosyjskiego admirała A. Wolskiego w okresie od 1 kwietnia do 1 grudnia 2018 roku FSB zatrzymało ok. $11 \%$ statków wchodzących, wychodzących i pływających w akwenie. Ponad $42 \%$ z nich zmierzało do bądź wracało z portów ukraińskich (869 zatrzymania) ${ }^{70}$. Na tej podstawie i własnych obliczeń strona ukraińska szybko ustaliła, że rosyjski admirał, prostując fakty blokowania, niechcący przyznał się do winy. W tym okresie do portów w Mariupolu i Berdiańsku zmierzało średnio statystycznie ok. 60 statków miesięcznie, łącznie ok. 480 jednostek. Kontrolę większości statków przeprowadzano w jednym i drugim kierunku (współczynnik wynosi 869: $480=1,81$ ) $^{71}$. Powyższe potwierdza działania Federacji Rosyjskiej skierowane na blokadę morską Ukrainy na Morzu Azowskim.

Po części działania Rosji były także odpowiedzią na sporadyczne próby Ukrainy egzekwowania swoich suwerennych praw w tym rejonie. 25 marca morskie oddziały Straży Granicznej Ukrainy zatrzymały statek rybacki „Nord” (z portu Kercz), oskarżając marynarzy z rosyjskimi paszportami o naruszenie zasad wjazdu i wyjazdu na terytorium okupowanego Krymu. W odpowiedzi Rosja zatrzymała kilka ukraińskich kutrów rybackich, dokonując następnie wymiany załogi kutra „Nord” na załogę kutra „ЯМК-0041"72.

Rosja w lutym 2016 roku bez porozumienia ze stroną ukraińską, łamiąc umowę bilateralną o Morzu Azowskim i Cieśninie Kerczeńskiej z 2003 roku $^{73}$, rozpoczęła budowę Mostu Kerczeńskiego. W tym czasie Ukraina podjęła decyzję o reformie swoich sił morskich, tworząc zamiast wojskowych baz morskich rejony morskie - Czarnomorski i Azowski. Podjęta została także decyzja o utworzeniu bazy sił morskich Ukrainy w Berdiańsku. W portowym mieście ulokowano batalion piechoty morskiej i zaplanowano rozmieszczenie 1-2 dywizjonów kutrów artyleryjskich. Dopiero agresywne działania Rosji na Morzu Azowskim w 2018 roku przyspieszyły ten proces. Na początku września tegoż roku Rada Bezpieczeństwa Narodowego i Obrony podjęła decyzję o utworzeniu zgrupowania okrętów i kutrów ukraińskiej marynarki na Morzu Azowskim. Pierwsze dwa kutry artyleryjskie typu „Giurza-M” w obawie przed agresywnymi działaniami Rosji w Cieśninie Kerczeńskiej zostały dostarczone drogą lądową. Podstawowym zadaniem Ukrainy na tym etapie konfliktu była nie tylko ochrona, ale także odblokowanie portów i zapewnienie swobody żeglugi swoim statkom i okrętom

${ }^{69}$ Ibidem.

70 Identyczne ogólne dane statystyczne podaje także w swoim artykule A. Mitrofanow, ale już bez szczegółowych informacji na temat zatrzymywanych statków zmierzających do i z portów ukraińskich. Wskazuje to na manipulacje w duchu rosyjskiej wojny informacyjnej.

71 „Чорноморські новини - Black Sea News”, https://www.blackseanews.net/read/147182, inf. 17.05.2019.

72 Захват судна «Норд», https://iz.ru/story/zakhvat-sudna-nord, inf. 14.07.2019.

73 Договір між Україною та Російською Федерацією про співробітництво у використанні Азовського моря і Керченської протоки, https://zakon.rada.gov.ua/laws/show/643_205, inf. 23.06.2019. 
w Cieśninie Kerczeńskiej i na Morzu Azowskim. Dnia 20 września dowództwo ukraińskiej marynarki skierowało dwa okręty wspomagania („Donbas” i „Koreć) z portu w Odessie do bazy w Berdiańsku. Pomimo eskorty oraz drobnych prowokacji ze strony rosyjskich okrętów jednostkom ukraińskim udało się dotrzeć do celu. Wypłynięcie pod koniec listopada 2018 roku dwóch kutrów artyleryjskich oraz holownika „Jany Kapu” z portu w Odessie do portu w Mariupolu był planowanym wcześniej działaniem z zakresu rozbudowy bazy Sił Morskich Ukrainy na Morzu Azowskim ${ }^{74}$. W kontekście bezpieczeństwa państwa ukraińskiego i obrony jego interesów powyższe działania zostały podjęte z dużym opóźnieniem i w stopniu minimalnym.

Operacja przebazowania okrętów ukraińskiej marynarki rozpoczęła się 23 listopada 2018 roku w składzie 4 okrętów. Oprócz wspomnianych wyżej kutrów artyleryjskich („Berdiańsk” i „Nikopol”), holownika „Jany Kapu” uczestniczył w niej okręt wspomagania „Horliwka”. Wykonawszy swoje zadanie, okręt wspomagania zawrócił do portu w Odessie. Pozostałe okręty kontynuowały wykonanie zadania. Według relacji dowództwa Sił Morskich Ukrainy 25 listopada kapitan kutra „Bierdiańsk” ok. godziny 4 nad ranem wysłał informację do portów w Kerczu (Krym) oraz Kaukaz (Rosja), a także na posterunek straży granicznej FSB FR o zamiarze przepłynięcia przez Cieśninę Kerczeńską. Informacja dotarła, ale ukraińskie okręty nie uzyskały odpowiedzi, co było celowym posunięciem strony rosyjskiej. O otrzymaniu przez port w Kerczu sygnału świadczy fakt, że kilka minut później dyspeczer portu poinformował rosyjski okręt marynarki wojennej „Suzdalec” o pojawieniu się ukraińskich okrętów ${ }^{75}$. Strona ukraińska skorzystała ze swojego prawa do swobody żeglugi przez Cieśninę Kerczeńską na podstawie prawa ukraińskiego, Konwencji ONZ o Prawie Morza (art. 17, 38), a także umowy bilateralnej o Morzu Azowskim i Cieśninie Kerczeńskiej z 2003 roku. Zachowując także zasadę bezpieczeństwa żeglugi, poinformowała odpowiednie służby portów morskich. Jednak dążąc do pełzającej aneksji Morza Azowskiego i de facto uznania aneksji Krymu strona rosyjska domaga się od strony ukraińskiej uzyskiwania zgody na przepłynięcie przez Cieśninę Kerczeńską. Pomiędzy informowaniem o przekroczeniu a uzyskiwaniem zgody na przekroczenie Cieśniny jest istotna różnica. Stosując tego typu wybiegi Rosja nie tylko łamie prawo międzynarodowe w zakresie swobody żeglugi, ale dąży metodą faktów dokonanych do zaakceptowania przez Ukrainę i społeczność międzynarodową aneksji Krymu i Cieśniny Kerczeńskiej. We wspomnianym artykule Aleksander Mitrofanow pisał, że ukraińskie okręty otrzymały zalecenie od Straży Granicznej FSB o nieprzekraczaniu granicy państwowej FR oraz niewpływaniu na morze terytorialne FR, a także konieczności dostosowania się do procedury przekraczania Cieśniny Kerczeńskiej, zatwierdzonych przez Ministra Transportu FR. Manipulacja polega na tym, że autor podobnie jak strona rosyjska a priori sprawę aneksji Krymu uznaje za zakończoną, a tak nie jest. Otóż

74 Що протиставила РФ «Донбасу» та «Корещъь» під час руху, https://mil.in.ua/shho-protystavylarf-donbasu-ta-korec-pid-chas-ruhu/, inf. 18.07.2019.

75 Російські кораблі здійснили напад на украӥнські катери, https://www.ukrmilitary.com/2018/11/ russian-ships-attacked-the-ukrainian-ships.html, inf. 11.07.2019. 
dla ukraińskich okrętów w dalszym ciągu jest to morze terytorialne Ukrainy i granica państwa ukraińskiego, dlatego naturalną odpowiedzią kapitana było stwierdzenie, że nie mają zamiaru przekraczać rosyjskiej granicy państwowej. Kolejna manipulacja dotyczy zapowiedzi przepłynięcia przez cieśninę. Zarówno w regulacjach ukraińskich, jak i rosyjskich występuje procedura podawania zamiaru przepłynięcia $z$ wyprzedzeniem 48 i 24 godziny, a ostateczne jej potwierdzenia 4 godziny przed przepłynięciem. Autor artykułu wspomniał o ukraińskich okrętach, które nie zastosowały się do tej procedury. Natomiast nie podał w swoim tekście faktu, że rosyjskie okręty marynarki wojennej i ochrony wybrzeża FSB regularnie w ten dzień pokonujące cieśninę też tej procedury nie przestrzegały. Wynika to z faktu, że ukraińskie i rosyjskie regulacje zawierają specjalny tryb żeglugi dla okrętów marynarki wojennej ${ }^{76}$.

Powyższe utwierdza w przekonaniu, że strona rosyjska celowo dążyła do zaostrzenia sytuacji w cieśninie celem zmuszenia strony ukraińskiej siłą do uznania de facto aneksji Półwyspu Krymskiego i Cieśniny Kerczeńskiej. Potwierdza to również rozwój wydarzeń w cieśninie z udziałem rosyjskich i ukraińskich okrętów.

Rosyjski okręt ochrony wybrzeża FSB „Don”, kutry typu „Sobol” i „Mangust” oraz wspomniany wyżej niszczyciel „Suzdalec”, niebezpiecznie manewrując w pobliżu ukraińskich okrętów, podjęły próbę zablokowania ostatnim możliwości zbliżenia się do Cieśniny Kerczeńskiej. Później okręt „Don” podjął kilka prób staranowania ukraińskiego holownika „Jana Kapu”. Podjęte przez stronę rosyjską działania, które zostały udokumentowane i są powszechnie dostępne, jednoznacznie pokazują, że zagrażały one bezpieczeństwu żeglugi i były złamaniem prawa międzynarodowego oraz porozumień bilateralnych. Rosyjskim okrętom nie udało się sprowokować strony ukraińskiej do otwarcia ognia, co dałoby Rosjanom pretekst do siłowego przejęcia ukraińskich okrętów.

Około południa ukraińskie okręty, już bez cienia wątpliwości rozpoznane przez stronę rosyjską, zbliżyły się do Cieśniny Kerczeńskiej, gdzie wstrzymano żeglugę oraz rozpoczęto akcję jej blokowania. W tym celu wykorzystano tankowiec oraz holowniki, a służby portowe jako oficjalną podały wersję tankowca osiadłego na mieliźnie, który był odholowywany celem przepuszczenia rosyjskich okrętów. Następnie ukraińskie okręty czekały w Cieśninie Kerczeńskiej około 6 godzin na możliwość przepłynięcia przez nią. Nie wytrzymuje krytyki także twierdzenie A. Mitrofanova o rzekomym zagrożeniu ze strony małych ukraińskich kutrów artyleryjskich dla Mostu Kerczeńskiego, który już w tym momencie był strzeżony przez 2 okręty Floty Czarnomorskiej, 6 kutrów Służby Ochrony Wybrzeża FSB oraz grupę wsparcia lotniczego (Su-25). Interesujące jest to, że strona rosyjska nie podejmowała prób przejęcia ukraińskich okrętów oczekujących kilka godzin na przejście przez Cieśninę Kerczeńską. Podjęła takie działania wtedy, kiedy ukraińskie okręty zrezygnowały z tego zamiaru i rozpoczęły powrót do Odessy. Dopiero wówczas wystosowano w formie ultymatywnej polecenie do zatrzy-

76 Наказ Міністерства Транспорту України про затвердження Правил плавання суден Керч-Єнікальським каналом і підхідними каналами до нього від 9.10.2002, https://zakon. rada.gov.ua/laws/show/z0973-02, inf. 12.07.2019. 
mania się, a następnie ukraińskie okręty zostały ostrzelane przez Rosjan i przejęte już poza strefą morza terytorialnego wokół Krymu. Fakt naruszenia immunitetu okrętów innego państwa oraz akt agresji A. Mitrofanov pokrętnie tłumaczy różnicą w pomiarach koordynat strony rosyjskiej i ukraińskiej ${ }^{77}$.

Powyższe świadczy, że okręty ukraińskie zachowały się zgodnie z normami prawa międzynarodowego oraz ustawodawstwa ukraińskiego. Trudno oczekiwać, że w sytuacji de facto konfliktu rosyjsko-ukraińskiego oraz de iure sporu między państwami w sprawie przynależności Półwyspu Krymskiego i Cieśniny Kerczeńskiej strona ukraińska będzie godziła się na bezwarunkowe respektowanie narzucanych jej wewnętrznych rosyjskich regulacji, mając zapewnioną w obecnych warunkach swobodę żeglugi na podstawie umowy bilateralnej. Otwarte pozostaje pytanie, czy Rosja musiała prowadzić do eskalacji napięcia oraz zablokowania Kanału Kercz-Jenikale. Sprawując de facto jurysdykcję nad cieśniną, FR mogła, stosując się do rosyjsko-ukraińskiej umowy z 2003 roku, zastosować specjalny tryb wobec ukraińskich okrętów, małych kutrów niestwarzających żadnego zagrożenia dla jej bezpieczeństwa. Wybrano wariant siłowy i to w momencie opuszczenia przez ukraińskie okręty Cieśniny Kerczeńskiej i morza terytorialnego wokół Krymu. Potwierdza to dążenia Rosji do faktycznej aneksji nie tylko Krymu, ale także Morza Azowskiego oraz istotnego ograniczenia bądź zlikwidowania morskiego potencjału Ukrainy. Wstrzymanie procesu przekazania najbardziej wartościowych okrętów ukraińskiej marynarki po aneksji półwyspu (2014) jedynie potwierdza to przypuszczenie. Nie wytrzymuje krytyki także stwierdzenie, że Rosja jedynie broniła swojego terytorium.

Społeczność międzynarodowa potępiła działania Rosji w Cieśninie Kerczeńskiej oraz przejęcie ukraińskich okrętów i wzięcie do niewoli ukraińskich marynarzy. $\mathrm{W}$ jednym z raportów Rady Praw Człowieka ONZ podkreślono, że „z powodu kontynuacji okupacji Krymu przez FR, nadal istnieje międzynarodowy konflikt zbrojny między dwoma państwami na Krymie, a międzynarodowe prawo humanitarne nadal ma tam zastosowanie”. Ponadto w dokumencie stwierdzono, że pomimo tego „wrogie zderzenie jednostek sił zbrojnych dwóch suwerennych państw dnia 25 listopada 2018 r. jest wystarczającym powodem do stosowania międzynarodowego prawa humanitarnego". Na tej podstawie zatrzymanych członków załogi należy uznać za jeńców wojennych chronionych przez trzecią konwencję genewską. Dopiero właściwy trybunał może ustalić inaczej ${ }^{78}$.

Zgromadzenie Parlamentarne Rady Europy potępiło użycie siły i przejęcie przez Rosję ukraińskich okrętów w Cieśninie Kerczeńskiej. W rezolucji podkreślono, że zgodnie z wciąż obowiązującym rosyjsko-ukraińskim porozumieniem o Morzu Azowskim i Cieśninie Kerczeńskiej należy je traktować jako wody wewnętrzne oby-

77 Війна у Керченській протоці: таран, итурмовики та захоплення украйнських кораблів, «Українська правда» 25.11.2018.

78 Report on the human rights situation in Ukraine 16 November 2018 to 15 February 2019, https:// documents-dds-ny.un.org/doc/UNDOC/GEN/G19/073/84/PDF/G1907384.pdf?OpenElement, inf. 25.06.2019. 
dwu państw. Swobodny przepływ statków handlowych i okrętów wojennych obydwu państw powinien być respektowany i zapewniony. Zgromadzenie wezwało Rosję także do zwolnienia ukraińskich okrętów i żołnierzy, zapewnienia swobody żeglugi przez Morze Azowskie i Cieśninę Kerczeńską zgodnie z rosyjsko-ukraińskim porozumieniem bilateralnym oraz Konwencją o Prawie Morza. Ponadto stronę rosyjską wezwano do powstrzymania się od użycia siły w sytuacji odmiennego traktowania przez nią sytuacji prawnej związanej z domniemanym naruszeniem granicy oraz korzystania $\mathrm{w}$ takich sytuacjach $\mathrm{z}$ międzynarodowych procedur rozwiązywania sporów. Obydwie strony wezwano do powstrzymania się od dalszej eskalacji napięcia oraz do respektowania umów bilateralnych i międzynarodowych. Ponadto RE po raz kolejny poparła suwerenność i integralność terytorialną Ukrainy, uznała wybudowany Most Kerczeński za nielegalny oraz potępiła ograniczanie przez Rosję żeglugi na Morzu Azowskim. Ponadto przychyliła się do propozycji Niemiec i Francji wysłania misji obserwacyjnej OBWE, której mandat rozciąga się na cały obszar Ukrainy, także na Krym i do Cieśniny Kerczeńskiej ${ }^{79}$.

Podczas wizyty w Kijowie 1 grudnia 2018 r. szef polskiego MSZ Jacek Czaputowicz powiedział, że „Ukraina jest ofiarą trwającej agresji rosyjskiej, której pierwszym aktem była nielegalna aneksja Krymu, następnie wywołanie i podsycanie konfliktu zbrojnego na wschodzie kraju, a najnowszą odsłoną - otwarty atak na ukraińskie okręty zmierzające na Morze Azowskie"80. Minister powtórzył stanowisko resortu w tej sprawie wydane kilka dni wcześniej, w którym działania Rosji uznano za agresywne i niezgodne $\mathrm{z}$ normami prawa międzynarodowego, $\mathrm{w}$ tym naruszenia suwerenności i integralności terytorialnej Ukrainy. W ocenie polskiego MSZ Rosja „po nielegalnej okupacji Krymu, podsycaniu konfliktu w Donbasie, budowie Mostu Kerczeńskiego bez zgody władz w Kijowie, pogwałciła także zasadę swobody żeglugi"s1.

Agresywne działania Rosji na Morzu Azowskim i w Cieśninie Kerczeńskiej ograniczające bądź uniemożliwiające swobodę żeglugi w tym akwenie spotkały się z krytyką większości organizacji międzynarodowych, w tym UE i NATO oraz przywódców wielu wiodących państw (USA, Niemcy, Francji, Wielkiej Brytanii).

Na podstawie wniosku skierowanego przez MSZ Ukrainy Międzynarodowy Trybunał Prawa Morza 25 maja 2019 roku orzekł za stosowne „w okolicznościach niniejszej sprawy przewidzieć środki tymczasowe zobowiązujące Federację Rosyjską do uwolnienia trzech okrętów marynarki wojennej i 24 zatrzymanych ukraińskich żołnierzy oraz do umożliwienia im powrotu na Ukrainę". Trybunał oświadczył, że znane jest mu sta-

79 The escalation of tensions around the Sea of Azov and the Kerch Strait and threats to European security, Resolution 2259 (2019), http://assembly.coe.int/nw/xml/XRef/Xref-XML2HTML-en.asp?fileid=25419\&lang=en, inf. 15.07.2019.

80 Minister Czaputowicz w Kijowie o sytuacji bezpieczeństwa na Ukrainie, https://www.gov.pl/web/dyplomacja/minister-czaputowicz-w-kijowie-o-sytuacji-bezpieczenstwa-na-ukrainie, inf. 23.07.2019.

${ }^{81}$ MSZ o sytuacji w Cieśninie Kerczeńskiej: Z cała moca potępiamy agresywne działania Rosji, https:// www.tvp.info/40142229/msz-o-sytuacji-w-ciesninie-kerczenskiej-z-cala-moca-potepiamyagresywne-dzialania-rosji, inf. 24.07.2019. 
nowisko Rosji, zaś w działaniach strony ukraińskiej nie znajduje znamion prowokacji wojskowej oraz skrytych działan. Wyraźnie stwierdził przy tym, że w tym przypadku mamy do czynienia ze sporem między państwami, w ramach którego strona ukraińska wyrażała gotowość do rozmów, a strona rosyjska takowych unikała (wyczerpała się możliwość porozumienia). Trybunał nie podzielił także stanowiska Rosji w tym, że jego jurysdykcja nie rozciąga się na tego typu sprawy. Rosja na użytek procesu twierdziła, że całe zderzenie należy traktować jako operację wojskową, wtedy na użytek wewnętrzny i międzynarodowy swoje działania przedstawiała jako operację policyjną służącą ochronie granic państwa. Trybunał zauważył, że samo przejście okrętów wojennych przez Cieśninę Kerczeńską nie musi oznaczać działań militarnych, zaś siłowe zatrzymanie ukraińskich marynarzy oraz wytoczenie im procesu karnego potwierdzają fakt prowadzenia operacji policyjnej. Istotą sporu obydwu państw jest egzekwowanie swoich suwerennych praw, co rozstrzygnie powołany w tym celu trybunał. Ponadto zasadne ze strony Ukrainy jest domaganie się od strony rosyjskiej respektowania immunitetu swoich okrętów. Trybunał jednoznacznie stwierdził, że działania podjęte przez Rosję mogły nieodwracalnie naruszyć prawa Ukrainy do immunitetu okrętów jej marynarki wojennej i ich żołnierzy ${ }^{82}$.

W celu rozwiązania sporu pomiędzy Ukrainą a Rosją w sprawie suwerennych praw stron w wodach Morza Czarnego i Azowskiego oraz Cieśninie Kerczeńskiej powołano specjalny Trybunał Arbitrażowy (załącznik VII Konwencji ONZ Prawo Morza). Odmienne stanowisko w tej sprawie prezentuje polski badacz Jakub Wojas, uważając, że ze względu na fakt trwającego międzynarodowego konfliktu zbrojnego pomiędzy Rosją a Ukrainą pierwszeństwo w zastosowaniu ma międzynarodowe prawo humanitarne ${ }^{83}$.

Podsumowując, możemy jednoznacznie stwierdzić, że działania Federacji Rosyjskiej w Cieśninie Kerczeńskiej w listopadzie 2018 roku należy określić jako akt agresji wobec państwa ukraińskiego i naruszenie immunitetu jego okrętów. Analizując tzw. incydent w Cieśninie Kerczeńskiej, należy wziąć pod uwagę wciąż trwający konflikt pomiędzy Rosją a Ukrainą. Ponadto powinno się rozważyć bezprawne z punktu widzenia prawa międzynarodowego przejęcie przez Rosję kontroli nad Cieśniną Kerczeńską, budowę Mostu Kerczeńskiego oraz działania zmierzające do ograniczenia żeglugi floty handlowej Ukrainy i państw trzecich zmierzających do portów ukraińskich (Mariupol, Berdianśk).

Powyższe działania Moskwy są zbieżne z założeniami powrotu do polityki imperialnej, zakładającej m.in. dominację Rosji w rejonie Morza Czarnego i Azowskiego. W kontekście analizy sytuacji geopolitycznej w regionie rosyjscy badacze bardzo często piszą, że powstanie niepodległej Ukrainy jako państwa morskiego posiadającego Krym oraz podział radzieckiej Floty Czarnomorskiej w sposób znaczący zmniejszyło po-

82 Tribunal prescribes provisional measures ordering the Russian Federation to release three Ukrainian naval vessels and their 24 servicemen, https://www.itlos.org/fileadmin/itlos/documents/press_releases_english/PR_284_En.pdf

83 J. Wojas, op. cit., s. 107-127. 
tencjał obronny Południa Rosji oraz wpływy Federacji Rosyjskiej na Morzu Czarnym i Śódziemnym. Współpraca Gruzji, a głównie Ukrainy z państwami NATO w ramach Partnerstwa dla Pokoju również było postrzegane jako zagrożenie i ograniczenie rosyjskich wpływów w regionie ${ }^{84}$. Najdobitniej o zamiarach Rosji w tym regionie świadczy fragment $z$ książki Aleksandra Dugina, iż „absolutnym imperatywem rosyjskiej geopolityki na czarnomorskim wybrzeżu jest totalna i niczym nie ograniczona kontrola Moskwy nad wybrzeżem Ukrainy i Abchazji. [...] Te sektory należy radykalnie oderwać od wpływu talassokracji, zarówno tej z Zachodu, jak i tej z Turcji, a nawet z Grecji. Północne wybrzeże Morza Czarnego powinno należeć wyłącznie do euroazjatyckiej strefy i podlegać Moskwie" 85 .

Streszczenie: Studium przypadku określanego mianem incydentu w Cieśninie Kerczeńskiej z uwzględnieniem uwarunkowań związanych z rosyjską agresją, aneksją i okupacją Krymu (2014) oraz agresywne działania podjęte przez Rosję wobec okrętów ukraińskiej marynarki wojennej jesienią 2018 r. podlegają jednoznacznej ocenie jako akt agresji. Powyższe wydarzenia należy rozpatrywać także w kontekście kontynuowania przez Federację Rosyjską niewypowiedzianej wojny wobec Ukrainy oraz dążenia do przejęcia całkowitej kontroli nad Morzem Azowskim i ograniczenia żeglugi floty handlowej Ukrainy i państw trzecich w kierunku portów ukraińskich. Działania Federacji Rosyjskiej mieszczą się w ramach paradygmatu polityki imperialnej, stanowią ewidentne pogwałcenie norm prawa międzynarodowego oraz suwerenności i integralności terytorialnej państwa ukraińskiego.

Słowa kluczowe: agresja, Cieśnina Kerczeńska, wojna rosyjsko-ukraińska

\section{Инцидент или акт агрессии в Керченском проливе?}

Аннотация: Тематическое исследование, именуемое инцидентом в Керченском проливе, с учетом условий, связанных с российской агрессией, аннексией и оккупацией Крыма (2014 г.), а также агрессивных действий, предпринятых Россией против кораблей украинского флота осенью 2018 г., подлежит однозначной оценке как акт агрессии. Вышеуказанные события следует также рассматривать в контексте продолжения Российской Федерацией необъявленной войны против Украины и стремления получить полный контроль над Азовским морем и ограничить движение торгового флота Украины и третьих стран в направлении украинских портов. Действия Российской Федерации находятся в рамках парадигмы имперской политики, В то время как они представляют собой явное нарушение норм международного права, а также суверенитета и территориальной целостности украинского государства.

Ключевые слова: агрессия, Керченский пролив, российско-украинская война

84 И. Юрченко, Геополитические особенности Черноморского региона в контексте обеспечения Юга Росии, «Вестник РУДН. Международные отношения» 2008, № 3, s. 18-23.

85 А. Дугин, Основы геополитики. Геополитическое будущее Росии, Москва 2000, s. 349. 


\section{Incident or act of aggression in the Kerch Strait?}

Abstract: The case study referred to as the incident in the Kerch Strait, taking into account the fact of
Russian aggression, annexation and occupation of Crimea (2014), as well as the aggressive actions
taken by Russia against the ships of the Ukrainian Navy in the autumn of 2018, are subject to explicit
assessment as an act of aggression. The above-mentioned events should also be considered in the
context of the Russian Federation's continuation of the undeclared war against Ukraine and the desire
to take full control over the Sea of Azov and limit the navigation of the merchant fleet of Ukraine and
third countries towards Ukrainian ports. The actions of the Russian Federation fall within the frame-
work of the imperial policy paradigm, while they constitute an evident violation of the norms of interna-
tional law, as well as the sovereignty and territorial integrity of the Ukrainian state.

Keywords: aggression, Kerch Strait, Russian-Ukrainian war

\section{Bibliografia}

"Chornomors'kinovyny - Black Sea News", https://www.blackseanews.net/read/147182, inf. 17.05.2019. «Samooborona» Krymu: yikh znayut'v oblychchya, https://ua. krymr.com/a/samooborona-krymu-ih-znaiut-v-oblychchia/29492740.html, inf. 20.08.2019.

"Vyshky Boyka» znayshly po trekakh buksyriv i foto viys'kovos/uzhbovtsiv RF, https://informnapalm.org/ ua/vyshky-bojka-znajshly-po-trekah-buksyriv-i-foto-vijskovosluzhbovtsiv-rf/, inf. 20.06.2019.

Above us only stars, https://www.c4reports.org/aboveusonlystars, inf. 18.05.2019.

Aleksandrova E., Setsesiya Kryma: poisk novoy normativnoy teorii prava na setsesiyu, «Pravovaya initsiativa» 2015, № 1.

Bieleń S., Powrót do Realpolitik w stosunkach Rosji z Zachodem jako konsekwencja konfliktu na Ukrainie, [w:] Implikacja konfliktu ukraińskiego dla polityki zagranicznej i bezpieczeństwa Polski. Aspekty polityczne, wojskowe, gospodarcze oraz społeczne, red. K. Czornik, M. Lakomy, M. Stolarczyk, Katowice 2015.

Bieleszczuk B. i in., Raport PISM: Energia i obronność w regionie nordycko-bałtyckim, Warszawa 2018. Bierzanek R., Symonides J., Prawo międzynarodowe publiczne, Wydawnictwo Lexis Nexis, Warszawa 2004.

Borowik B., Kirwiel E., The Media System in the Russian Federation. Selected issues, "Wschód Europy. Studia humanistyczno-społeczne" 2018, nr 1. DOl: https://doi.org/10.17951/we.2018.4.1.13.

Deklaracja zasad prawa międzynarodowego dotyczących przyjaznych stosunków i współdziałania państw zgodnie z Kartą Narodów Zjednoczonych, przyjęta na podstawie Rezolucji Zgromadzenia Ogólnego 2625(XXV), 24 października 1970 r.

Dohovir mizh Ukrayinoyu ta Rosiys'koyu Federatsiyeyu pro spivrobitnytstvo u vykorystanni Azovs'koho morya i Kerchens'koyi protoky, https://zakon.rada.gov.ua/laws/show/643_205, inf. 23.06.2019.

Doklad «Mezhdu peremiriyem i voynoy», Pravozashchitnyy tsentr «Memorial», https://memohrc.org/sites/all/themes/memo/templates/pdf.php?pdf=/sites/default/files/old/files/1658.pdf

Dugin A., Osnovy geopolitiki. Geopoliticheskoye budushcheye Rossii, Moskva 2000.

Dura M., Kryzys na Morzu Azowskim. „Nieważne kto ma rację, ważne kto ma rakiety"', https://www. defence24.pl/kryzys-na-morzu-azowskim-nie-wazne-kto-ma-racje-wazne-kto-ma-rakiety, inf. 12.05.2019. 
Gerasimov V., Tsennost' nauki v predvidenii, «Voyenno-promyshlennyy kur'yer», № 8(476).

Góralczyk W., Sawicki S., Prawo międzynarodowe publiczne w zarysie, Warszawa 2015.

Karta Narodów Zjednoczonych, http://www.bb.po.gov.pl/Prawa/PNZ/KNZ.pdf, inf. 22.07.2019.

Kissinger H., Dyplomacja, Warszawa 2002.

Kopaliński W., Stownik wyrazów obcych i zwrotów obcojęzycznych z almanachem, PWN, Warszawa 1994.

Korotkyy T., Khendel' N., Mizhnarodno-pravovyy analiz sytuatsiyi v Azovs'komu mori ta Kerchens'kiy prototsi, «Ukrayins'kyy chasopys mizhnarodnoho prava» 2018, № 2.

Kostrov V., Khronika kryms'koho protystoyannya, «Viche» 2014, № 7.

Kotlyarov I.I., Puzyreva Yu.V., Grazhdanskaya voyna v Ukraine: mezhdunarodnoye pravo i ugolovnaya otvetstvennost' individov za soversheniye mezhdunarodnykh prestupleniy, "Moskovskiy zhurnal mezhdunarodnogo prava" 2014, № 4.

Lakomy M., Przebieg i uwarunkowania konfliktu na Ukrainie, [w:] Implikacja konfliktu ukraińskiego dla polityki zagranicznej i bezpieczeństwa Polski. Aspekty polityczne, wojskowe, gospodarcze oraz spoteczne, red. K. Czornik, M. Lakomy, M. Stolarczyk, Katowice 2015.

Mała encyklopedia prawa, red. U. K. Kalina-Prasznice, Wydawnictwo C.H. Beck, Warszawa 2005.

Marek M., Militaryzacja Morza Azowskiego - rosyjskie uderzenie w gospodarkę Ukrainy, https://www.defence24.pl/militaryzacja-morza-azowskiego--rosyjskie-uderzenie-w-gospodarke-ukrainy-analiza, inf. 18.05.2019.

Marusyak 0., Aneksiya Krymu Rosiys'koyu Federatsiyeyu yak zlochyn ahresiyi proty Ukrayiny: mizhnarodnopravovi aspekty, Chernivtsi 2016.

Matematika i referendum po Krymu, https://trv-science.ru/2014/03/25/matematika-i-referendum-po-krymu/, dostęp inf. 14.12.2019.

Minister Czaputowicz w Kijowie o sytuacji bezpieczeństwa na Ukrainie, https://www.gov.pl/web/dyplomacja/minister-czaputowicz-w-kijowie-o-sytuacji-bezpieczenstwa-na-ukrainie, dostęp inf. 23.07.2019.

Mitrofanov A., Incydent w Cieśninie Kerczeńskiej, „Okręty Wojenne” 2019, nr 1.

Model' ta reformuvannya Viys'kovo-Mors'kykh Syl Zbroynykh Syl Ukrayiny (2015--2020), http://defense-ua.com/rus/hotnews/?id=45421, inf. 21.05.2019.

MSZ o sytuacji w Cieśninie Kerczeńskiej: Z całą mocą potępiamy agresywne działania Rosji, https://www. tvp.info/40142229/msz-o-sytuacji-w-ciesninie-kerczenskiej-z-cala-moca-potepiamy-agresywnedzialania-rosji, inf. 24.07.2019.

Nakaz Ministerstva Transportu Ukrayiny pro zatverdzhennya Pravyl plavannya suden KerchYenikal's'kym kanalom i pidkhidnymy kanalamy do n'oho vid 9.10.2002, https://zakon.rada.gov. ua/laws/show/z0973-02, inf. 12.07.2019.

Nowak A., Koniec podległości, „Nowa Europa Wschodnia” 2016, nr 1.

Ochman P. , Wojas J., Współczesne znaczenie aktu wypowiedzenia wojny - uwagi w kontekście konfliktu na wschodzie Ukrainy, „Bezpieczeństwo. Teoria i praktyka” 2015, nr 3.

Ozhegov S., Shvedova Yu., Tolkovyy slovar' russkogo yazyka, Moskva 2002.

Perepelytsya H., Ukrayina-Rosiya. Viyna v umovakh spivisnuvannya, Kyyiv 2015.

Piskrzyńska K., Kryzysy i konflikty międzynarodowe w wymiarze regionalnym. Rozważania teoretyczne, „De Doctrina Europea., Roczniki Instytutu Europeistyki” 2008, vol. V. 
Protopopov A., Koz'menko V., Elmanova N., Istoriya mezhdunarodnykh otnosheniy i vneshney politiki Rossii 1648-2005, Moskva 2006.

Putin rasskazal „Rossii 1”, kak vernul Krym i spas Yanukovicha, http://www.vesti.ru/doc.html?id=2412450, inf. 25.08.2014.

Raś M. , Polityka Rosji wobec Ukrainy i jej implikacje dla tadu międzynarodowego w Europie, [w:] Implikacja konfliktu ukraińskiego dla polityki zagranicznej i bezpieczeństwa Polski. Aspekty polityczne, wojskowe, gospodarcze oraz społeczne, red. K. Czornik, M. Lakomy, M. Stolarczyk, Katowice 2015.

Report on the human rights situation in Ukraine 16 November 2018 to 15 February 2019, https://documents-dds-ny.un.org/doc/UNDOC/GEN/G19/073/84/PDF/G1907384.pdf?OpenElement, inf. 25.06.2019.

Rezolyutsiya, prinyataya General'noy Assambleyey 27 marta 2014 goda (68/262. Territorial'naya tselostnost' Ukrainy), http://daccess-dds-ny.un.org/doc/UNDOC/GEN/N13/455/19/PDF/N1345519.pdf?OpenElement, inf. 25.08.2014.

Rezul'taty obshchekrymskogo referenduma, http://www.rada.crimea.ua/referendum/resultaty;

Rosiya prodovzhuye nezakonnyy vydobutok pisku poblyzu Dzharylhacha, https://mil.in.ua/rosiyaprodovzhuye-nezakonnyj-vydobutok-pisku-poblyzu-dzharylgacha/, inf. 15.06.2019.

Rosiys'ki korabli zdiysnyly napad na ukrayins'ki katery, https://www.ukrmilitary.com/2018/11/russian-ships-attacked-the-ukrainian-ships.html, inf. 11.07.2019.

Rybakov Yu., Vooruzhënnaya agressiya - tyagchaysheye mezhdunarodnoye prestupleniye, Moskva 1980. Sankcje i Rosja, red. J. Ćwiek-Karpowicz, S. Secrieru, Warszawa 2015.

Savryga K.P., Ukrainskiy krizis i mezhdunarodnoye pravo: konflikt na vostoke Ukrainy i setsessiya Kryma, „Pravo i politika” 2015, № 7.

Shaptalov B., Iznanka rossiysko-ukrainskogo konflikta, ili kak possorilis' sosedi, Tsentrpoligraf 2016.

Shcho protystavyla RF «Donbasu» ta «Korets'» pid chas rukhu, https://mil.in.ua/shho-protystavyla-rfdonbasu-ta-korec-pid-chas-ruhu/, inf. 18.07.2019.

Shumilov M.M., "Sovremennyye konflikty i problemy ikh uregulirovaniya” (Uchebnometodicheskiy kompleks po kursu), Izdatel'stvo «SZAGS» 2004.

Soglasheniye mezhdu Rossiyskoy Federatsiyey i Ukrainoy o statuse i usloviyakh prebyvaniya Chernomorskogo flota Rossiyskoy Federatsii na territorii Ukrainy ot 28 maya $1997 \mathrm{~g}$., [w:] Rossiya-Ukraina 1990-2000. Dokumenty i materialy, t. 2, Moskva 2001.

Solovey V., Absolyutnoye oruzhiye. Osnovy psikhologicheskoy voyny imediamanipulirovaniya, «Izdatel'stvo «E» 2015.

Sovet Federatsii prinyal Zayavleniye v svyazi s 20-letney godovshchinoy nachala voyennoy operatsii NATO protiv Yugoslavii, http://council.gov.ru/events/news/102603/, inf. 17.07.2019.

Sovet pri Putine postavil pod somneniye rezul'taty krymskogo referenduma, http://www.stopfake.org/ sovet-pri-putine-postavil-pod-somnenie-rezultaty-krymskogo-referenduma/, inf. 5.07.2019.

Surkov V., Dolgoye gosudarstvo Putina, "Nezavisimaya gazeta” 11.02.2019.

The escalation of tensions around the Sea of Azov and the Kerch Strait and threats to European security, Resolution 2259 (2019), http://assembly.coe.int/nw/xml/XRef/Xref-XML2HTML-en.asp?fileid=25419\&lang=en, inf. 15.07.2019.

Tishkov S., Agressiya kak mezhdunarodnoye prestupleniye, Moskva 2017 (dissertatsiya, nauchnyy rukovoditel': prof. A. Avtonomov). 
Tribunal prescribes provisional measures ordering the Russian Federation to release three Ukrainian naval vessels and their 24 servicemen, https://www.itlos.org/fileadmin/itlos/documents/press_releases_ english/PR_284_En.pdf

U Haazi pryznachyly datu sudu shchodo porushen' Rosiyeyu mors'koho prava, https://mil.in.ua/u-gaazipryznachyly-datu-sudu-shhodo-porushen-rosiyeyu-morskogo-prava/, inf. 23.07.2019.

Viyna u Kerchens'kiy prototsi: taran, shturmovyky ta zakhoplennya ukrayins'kykh korabliv, «Ukrayins'ka pravda» 25.11.2018.

Voyennaya prokuratura Ukrainy obnarodovala spisok rossiyskikh podrazdeleniy, okkupirovavshikh Krym, https://gordonua.com/news/crimea/voennaya-prokuratura-ukrainy-obnarodovala-spisok-rossiys kih-podrazdeleniy-okkupirovavshih-krym-152672.html, inf. 18.07.2019.

Vyvedennya ukrayins'kykh korabliv z Krymu pryzupynyayet'sya, http://wartime.org.ua/11369-vivedennya-ukrayinskih-korablv-z-krimu-prizupinyayetsya-zm.html

Wasiuta O., Wasiuta S., Wojna hybrydowa Rosji przeciwko Ukrainie, Kraków 2017.

Wilk A., Rosyjska interwencja wojskowa na Krymie, http://www.osw.waw.pl/pl/publikacje/analizy/201403-05/rosyjska-interwencja-wojskowa-na-krymie, inf. 25.08.2014.

Wojas J., Incydent w Cieśninie Kerczeńskiej w świetle prawa międzynarodowego „Sprawy Międzynarodowe" 2019, nr 2. DOl: https://doi.org/10.35757/SM.2019.72.2.05.

Wojna hybrydowa Rosji przeciwko Ukrainie w latach 2014-2016, red. W. Baluk, M. Doroszko, Wydawnictwo UMCS, Lublin 2017.

Wojnicki Ł., Tak wygląda blokada Krymu przez Rosjan na satelitarnych mapach, http://wyborcza. pl/1,75399,15588138,Tak_wyglada_blokada_Krymu_przez_Rosjan_na_satelitarnych.html, inf. 12.06.2019.

Wojskowa Prokuratura Południowego Okręgu Ukrainy, http://www.vppdr.gp.gov.ua/ua/news.htmI?fp=10, inf. 20.02.2016.

Yurchenko I., Geopoliticheskiye osobennosti Chernomorskogo regiona v kontekste obespecheniya Yuga Rosii, «Vestnik RUDN. Mezhdunarodnyye otnosheniya» 2008, № 3.

Zadorozhniy 0., Aneksiya Krymu - mizhnarodnyy zlochyn, Kyyiv 2015 (0. Zadorozhnii, Russian doctrine of international law after the annexation of Crimea: Monograph, Kyiv 2016.

Zakhvat sudna «Nord», https://iz.ru/story/zakhvat-sudna-nord, dostęp inf. 14.07.2019.

Zięba R., Międzynarodowe implikacje kryzysu ukraińskiego, "Stosunki Międzynarodowe - International Relations" 2014, nr 2. 